\title{
Dissolved greenhouse gases (nitrous oxide and methane) associated with the naturally iron-fertilized Kerguelen region (KEOPS 2 cruise) in the Southern Ocean
}

\author{
L. Farías ${ }^{1}$, L. Florez-Leiva ${ }^{2}$, V. Besoain ${ }^{1,3}$, G. Sarthou ${ }^{4}$, and C. Fernández ${ }^{5,6}$ \\ ${ }^{1}$ Departamento de Oceanografía, Universidad of Concepción and Centro de Ciencia del Clima y \\ la Resiliencia (CR), Chile \\ ${ }^{2}$ Programa de Biología, Universidad del Magdalena, Santa Marta, Colombia \\ ${ }^{3}$ Escuela de Ciencias del Mar, Pontificia Universidad Católica de Valparaíso, Chile \\ ${ }^{4}$ LEMAR-UMR6539, CNRS-UBO-IRD-IFREMER, Place Nicolas Copernic, 29280 Plouzané, France \\ ${ }^{5}$ Sorbonne Universités, UPMC Univ Paris 06, UMR7621, Laboratoire d'Océanographie Microbienne, \\ Observatoire Océanologique, 66650 Banyuls/mer, France \\ ${ }^{6}$ Department of Oceanography, COPAS SA program and Interdisciplinary Center for Aquaculture Research \\ (INCAR), University of Concepción, Chile \\ Correspondence to: L. Farías (Ifarias@profc.udec.cl)
}

Received: 23 June 2014 - Published in Biogeosciences Discuss.: 21 August 2014

Revised: 9 February 2015 - Accepted: 23 February 2015 - Published: 24 March 2015

\begin{abstract}
The concentrations of greenhouse gases (GHGs), such as nitrous oxide $\left(\mathrm{N}_{2} \mathrm{O}\right)$ and methane $\left(\mathrm{CH}_{4}\right)$, were measured in the Kerguelen Plateau region (KPR). The KPR is affected by an annual microalgal bloom caused by natural iron fertilization, and this may stimulate the microbes involved in GHG cycling. This study was carried out during the KEOPS 2 cruise during the austral spring of 2011. Oceanographic variables, including $\mathrm{N}_{2} \mathrm{O}$ and $\mathrm{CH}_{4}$, were sampled (from the surface to $500 \mathrm{~m}$ depth) in two transects along and across the $\mathrm{KRP}$, the north-south (TNS) transect $\left(46^{\circ}-51^{\circ} \mathrm{S}, \sim 72^{\circ} \mathrm{E}\right)$ and the east-west (TEW) transect $\left(66^{\circ}-75^{\circ} \mathrm{E}, \sim 48.3^{\circ} \mathrm{S}\right)$, both associated with the presence of a plateau, polar front (PF) and other mesoscale features. The TEW presented $\mathrm{N}_{2} \mathrm{O}$ levels ranging from equilibrium (105\%) to slightly supersaturated $(120 \%)$ with respect to the atmosphere, whereas $\mathrm{CH}_{4}$ levels fluctuated dramatically, being highly supersaturated (120-970\%) in areas close to the coastal waters of the Kerguelen Islands and in the PF. The TNS showed a more homogenous distribution for both gases, with $\mathrm{N}_{2} \mathrm{O}$ and $\mathrm{CH}_{4}$ levels ranging from 88 to $171 \%$ and 45 to $666 \%$ saturation, respectively. Surface $\mathrm{CH}_{4}$ peaked at southeastern stations of the KPR (A3 stations), where a phytoplankton bloom was observed. Both gases responded significantly, but in contrasting ways $\left(\mathrm{CH}_{4}\right.$ accumulation and $\mathrm{N}_{2} \mathrm{O}$ de-
\end{abstract}

pletion), to the patchy distribution of chlorophyll $a$. This seems to be associated to the supply of iron from various sources. Air-sea fluxes for $\mathrm{N}_{2} \mathrm{O}$ (from -10.5 to 8.65 , mean $1.25 \pm 4.04 \mu \mathrm{mol} \mathrm{m}^{-2} \mathrm{~d}^{-1}$ ) and for $\mathrm{CH}_{4}$ (from 0.32 to 38.1, mean $10.01 \pm 9.97 \mu \mathrm{mol}^{-2} \mathrm{~d}^{-1}$ ) indicated that the KPR is both a sink and a source for $\mathrm{N}_{2} \mathrm{O}$, as well as a considerable and variable source of $\mathrm{CH}_{4}$. This appears to be associated with biological factors, as well as the transport of water masses enriched with $\mathrm{Fe}$ and $\mathrm{CH}_{4}$ from the coastal area of the Kerguelen Islands. These previously unreported results for the Southern Ocean suggest an intense microbial $\mathrm{CH}_{4}$ production in the study area.

\section{Introduction}

The increasing concentration of greenhouse gases (GHGs) in the troposphere, such as $\mathrm{CO}_{2}, \mathrm{~N}_{2} \mathrm{O}$ and $\mathrm{CH}_{4}$, affect the Earth's radiative balance. Additionally, the increasing concentration of ozone-depleting gases (such as chlorofluorocarbons and $\mathrm{N}_{2} \mathrm{O}$ ) in the stratosphere is weakening the ozone shield, permitting higher levels of damaging ultraviolet radiation to reach the Earth's surface. The relative potency of a 
GHG is determined by its respective residence time in the atmosphere (Cicerone and Orelamland, 1988), and the extent of magnitude of emissions to the atmosphere, of which the input/contribution from the ocean is considered to be important (IPCC, 2013).

Although oceans are generally considered to be a net source of GHGs, for example $\mathrm{N}_{2} \mathrm{O}$ and $\mathrm{CH}_{4}$, to the atmosphere, the oceanic distribution of these GHGs and the amount exchanged via the air-sea interface is highly variable (Nevison et al., 1995; Holmes et al., 2000; Rhee et al., 2009). Thus, source and sink behaviours of GHGs have been observed on different spatial and temporal scales. In general terms, these behaviours depend on biological and physical processes that promote outgassing or sequestering mechanisms. Physical and biological features of the Southern Ocean suggest the existence of a potential for both the production and removal of $\mathrm{CH}_{4}$ and $\mathrm{N}_{2} \mathrm{O}$ (Rees et al., 1999; Tilbrook and Karl, 1994), although very little information on dissolved $\mathrm{N}_{2} \mathrm{O}$ and $\mathrm{CH}_{4}$ distributions is currently available for the region. The substantial spatial variation in regional gas exchange could be due to the increased gas solubility in low-temperature Subantarctic waters, combined with either the downwelling associated with intermediate and deep water formation in the northern and southern part, respectively, of the Antarctic Zone. Further variation may be caused by the upwelling of deep and intermediate waters in the southern part of the Antarctic Polar Frontal Zone (Park and Vivier, 2012).

In different regions of the Southern Ocean, the surface layer is permanently supersaturated with $\mathrm{CH}_{4}$ (Bates et al., 1996; Tilbrook and Karl, 1994; Yoshida et al., 2011), but this is not the case for $\mathrm{N}_{2} \mathrm{O}$, which may occur in either underor supersaturated conditions (Law and Ling, 2001; Rees et al., 1997; Chen et al., 2014). Aside from physical processes affecting GHG concentrations in the water column and their concomitant air-sea fluxes, the concentrations also depend on organic matter $(\mathrm{OM})$ availability and oxygen levels, which determine whether aerobic or anaerobic respiration occurs (Codispoti et al., 2001; Reeburgh, 2007). The availability of dissolved iron $(d \mathrm{Fe})$ should also be included as a direct variable affecting the recycling of GHGs (through production and consumption), as several Fe-containing enzymes are required for GHG cycling, which are involved in the electron transfer chains in bacterial respiratory systems and nitrogen cycling (Arrieta et al., 2004; Kirchman et al., 2003; Morel and Price, 2003). Indirectly, $d \mathrm{Fe}$ stimulates ocean productivity, which can enhance carbon and nitrogen export from the euphotic zone to the subsurface (Boyd and Ellwood, 2010), resulting in an increase in microbial activities and mediate GHG production via nitrification (Fuhrman and Capone, 1991).

$\mathrm{N}_{2} \mathrm{O}$ is mainly produced during the first step of nitrification (the aerobic oxidation of $\mathrm{NH}_{4}^{+}$to $\mathrm{NO}_{2}^{-}$), as well as during partial denitrification (the anaerobic reduction of $\mathrm{NO}_{3}^{-} / \mathrm{NO}_{2}^{-}$to $\mathrm{N}_{2} \mathrm{O}$ ). $\mathrm{N}_{2} \mathrm{O}$ can also be consumed by com- plete denitrification via dissimilatory reduction to $\mathrm{N}_{2}$ (Codispoti and Cristiensen, 1985) or assimilatory $\mathrm{N}_{2} \mathrm{O}$ reduction to $\mathrm{NH}_{4}^{+}$(Farias et al., 2013). $\mathrm{CH}_{4}$, on the other hand, is mainly formed by methanogens during anaerobic OM degradation (Wuebble and Hayboe, 2002) or by methylotrophs during $\mathrm{CH}_{4}$ formation derived from transformations of methyl compounds such as methylphosphonate (MPn; Karl et al., 2008), dimethylsulfoniopropionate (DMSP; Damm et al., 2010) and dimethylsulfide (DMS; Florez-Leiva et al., 2013). In addition, $\mathrm{CH}_{4}$ can be consumed (oxidized) via aerobic methanotrophy (Hanson and Hanson, 1996). Since Southern Ocean waters are well oxygenated, the dominant mechanisms of production of the GHGs in surface waters are nitrification in the case of $\mathrm{N}_{2} \mathrm{O}$ (Nevison et al., 2003) and methanogenesis in suspended particles (Scranton and Brewer, 1977) and/or methylotrophy (Sun et al., 2011) for the case of $\mathrm{CH}_{4}$.

The main objective of the present study is to describe for first time the $\mathrm{N}_{2} \mathrm{O}$ and $\mathrm{CH}_{4}$ contents in the Southern Ocean under the influence of natural fertilization during the spring phytoplankton bloom in the Kerguelen Plateau region (KPR). The determination of the role of the Southern Ocean in $\mathrm{CH}_{4}$ and $\mathrm{N}_{2} \mathrm{O}$ air-sea exchange may be critical in understanding the factors that influence GHG cycling. This includes $d \mathrm{Fe}$ which comes from different sources within the KPR, inducing mesotrophic conditions associated with the coastal waters of the Kerguelen Islands and of the central Kerguelen Plateau, an area within the central plateau area of the KPR that demonstrates an annually recurrent phytoplanktonic bloom in the (Blain et al., 2008; Chever et al., 2010), and with the Antarctic PF and other mesoscale structures (Mongin et al., 2008; Lasbleiz et al., 2014).

\section{Methods}

\subsection{Study area}

Samples were collected within the KPR (Fig. 1) during the KEOPS 2 cruise at stations along the north-south transect (TNS; $46^{\circ}-51^{\circ} \mathrm{S}$ ) and the east-west transect (TEW; $66^{\circ}-75^{\circ} \mathrm{E}$ ). The cruise took place from 11 October to 11 December 2011 onboard the research vessel (RV) Marion Dufresne. Some of the stations were located in the naturally Fe-enriched polar front (PF) zone, in the coastal shelf waters of the Kerguelen Islands and within the southeastern KPR bloom (including the A3 Stations from the previous KEOPS 1 cruise). Station R-2, located east of the Kerguelen Plateau, was considered to be typical of high-nutrient, low-chlorophyll (HNLC) conditions (see Table 1). The positions of the stations were selected according to a strategy based on real-time ocean colour and altimetry satellite images (d'Ovidio et al., 2015). 
Table 1. General oceanographic features of the sampled stations during the KEOPS 2 cruise.

\begin{tabular}{|c|c|c|c|c|c|c|c|c|c|}
\hline $\begin{array}{l}\text { Biogeochemical } \\
\text { provinces }\end{array}$ & Stations & $\begin{array}{r}\text { Latitude } \\
{ }^{\circ} \mathrm{S}\end{array}$ & $\begin{array}{r}\text { Longitude } \\
{ }^{\circ} \mathrm{E}\end{array}$ & $\begin{array}{r}\text { Date } \\
\text { mm-dd-yy }\end{array}$ & $\begin{array}{r}\text { Bottom depth } \\
\text { (m) }\end{array}$ & $\begin{array}{r}\text { MLD } \\
(\mathrm{m})\end{array}$ & $\begin{array}{r}\text { Temperature } \\
\left({ }^{\circ} \mathrm{C}\right)\end{array}$ & Salinity & $\begin{array}{r}\text { Oxygen } \\
\left(\mu \mathrm{mol} \mathrm{L}^{-1}\right)\end{array}$ \\
\hline & OISO-6 & -44.59 & 52.06 & $10-15-11$ & 3260 & 110 & $3.68(3.66-3.68)$ & $33.80(33.80-33.81)$ & $317.4(314-318)$ \\
\hline & OISO-7 & -47.4 & 58.00 & $10-16-11$ & 4300 & 127 & $4.75(4.73-4.76)$ & $33.79(33.8-33.81)$ & $308.4(305-309)$ \\
\hline \multicolumn{10}{|l|}{$\mathrm{N}-\mathrm{S}$ transect } \\
\hline & A3-1 & $-50,38$ & 72.05 & $10-19-11$ & 535 & 181 & $1.68(1.68-1.73)$ & $33.89(33.85-33.91)$ & $325.9(321-327)$ \\
\hline & A3-2 & -50.38 & 72.05 & $10-16-11$ & 527 & 165 & $2.16(2.10-2.18)$ & $33.91(33.911-33.913)$ & $333.2(329-335)$ \\
\hline & TNS-10 & -50.12 & 72.07 & $10-21-11$ & 565 & 163 & $1.67(1.59-1.68)$ & $33.90(33.80-33.93)$ & $325.9(314-327)$ \\
\hline Eddy & TNS-9 & -49.47 & 72.12 & $10-21-11$ & 615 & 137 & $1.75(1.66-1.89)$ & $33.91(33.80-33.84)$ & $321.1(265-331)$ \\
\hline \multirow[t]{7}{*}{ Eddy } & TNS-8 & -49.27 & 72.14 & $10-21-11$ & 1030 & 139 & $2.11(2.06-2.12)$ & $33.869(33.86-33.87)$ & $329.4(324-328)$ \\
\hline & TNS-7 & -49.08 & 72.17 & $10-22-11$ & 1890 & 62 & $2.10(1.95-2.16)$ & $33.86(33.86-33.87)$ & $327.7(327-331)$ \\
\hline & TNS-6 & -48.48 & 71.18 & $10-22-11$ & 1885 & 67 & $2.32(2.23-2.42)$ & $33.846(33.84-33.85)$ & $327.6(315-316)$ \\
\hline & TNS-5 & -48.28 & 72.12 & $10-22-11$ & 2060 & 114 & $2.22(2.09-2.26)$ & $33.85(33.85-33.86)$ & $326.7(323-328)$ \\
\hline & TNS-3 & -47.05 & 71.55 & $10-23-11$ & 540 & 111 & $2.17(2.06-2.26)$ & 33.89 (33.88-33.89) & $307.6(304-310)$ \\
\hline & TNS-2 & -47.19 & 71.42 & $10-23-11$ & 520 & 65 & $3.60(3.38-3.67)$ & 33.69 (33.68-33.69) & $318.6(317-319)$ \\
\hline & TNS-1 & -46.49 & 71.30 & $10-23-11$ & 2280 & 45 & $4.02(3.96-4.13)$ & $33.71(33.71-33.72)$ & $316.1(315-318)$ \\
\hline HNLC & $\mathrm{R}-2$ & -50.21 & 66.43 & $10-23-11$ & 2300 & 111 & $2.11(2.06-2.14)$ & $33.78(33.77-33.78)$ & $326.7(326-327)$ \\
\hline \multicolumn{10}{|l|}{ E-W transect } \\
\hline (Shelf) & TEW-1 & $-49,08$ & 69.50 & $10-31-11$ & 86 & 16 & $3.27(3.17-3.36)$ & $33.61(33.61-33.62)$ & $344.16(340-345)$ \\
\hline (Shelf) & TEW-2 & $-48,53$ & 70.39 & $10-31-11$ & 84 & 40 & $2.55(2.49-2.68)$ & $33.75(33.75-33.76)$ & $332,0(327-337)$ \\
\hline \multirow[t]{3}{*}{ (Shelf) } & TEW-3 & 48.47 & 71.01 & $10-31-11$ & 565 & 62 & $2.17(2.12-2.31)$ & $33.86(33.86-33.87)$ & $329.69(328-331)$ \\
\hline & TEW-4 & -48.37 & 71.28 & $11-01-11$ & 1585 & 95 & $2.54(2.41-2.60)$ & $33.85(33.85-33.86)$ & $334.60(331-337)$ \\
\hline & TEW-5 & -48.28 & 72.47 & $11-01-11$ & 2275 & 60 & $2.51(2.39-2.60)$ & $33.84(33.84-33.85)$ & $331.42(327-336)$ \\
\hline \multirow[t]{2}{*}{ (NPF) } & TEW-7 & $-48,27$ & 73.59 & $11-02-11$ & 2510 & 17 & $4.02(3.91-4.10)$ & $33.78(33.784-33.79)$ & 315.95 (346-349) \\
\hline & TEW-8 & $-48,28$ & 75.19 & $11-02-11$ & 2786 & 22 & $4.15(4.08-4.18)$ & $33.76(33.76-33.77)$ & $338.75(347-350)$ \\
\hline \multicolumn{10}{|c|}{ Time series stations } \\
\hline & E-1 & -48.27 & 72.11 & $10-28-11$ & 2056 & 84 & $2.48(2.36-2.54)$ & $33.85(33.84-33.85)$ & $331.54(328-333)$ \\
\hline & E-2 & -48.31 & 72.04 & $11-01-11$ & 2003 & 42 & $2.42(2.28-2.56)$ & $33.85(33.85-33.86)$ & $331.68(329-333)$ \\
\hline & E-3 & -48.48 & 71.58 & $11-03-11$ & 1915 & 41 & $2.74(2.60-2.81)$ & $33.84(33.84-33.85)$ & $332.08(331-332)$ \\
\hline & E-4W & -48.45 & 71.25 & $11-11-11$ & 1384 & 67 & $2.36(2.07-2.51)$ & $33.90(33.90-33.91)$ & $329.95(326-332)$ \\
\hline & E-4E & -48.42 & 72.33 & $11-12-11$ & 2210 & 77 & $3.15(2.78-3.19)$ & $33.84(33.83-33.85)$ & $329.89(326-331)$ \\
\hline & E-5 & -48.24 & 71.50 & $11-18-11$ & 1920 & 36 & $2.53(2.50-2.62)$ & 33.85 (33.85-33.85) & $326.97(330-333)$ \\
\hline
\end{tabular}

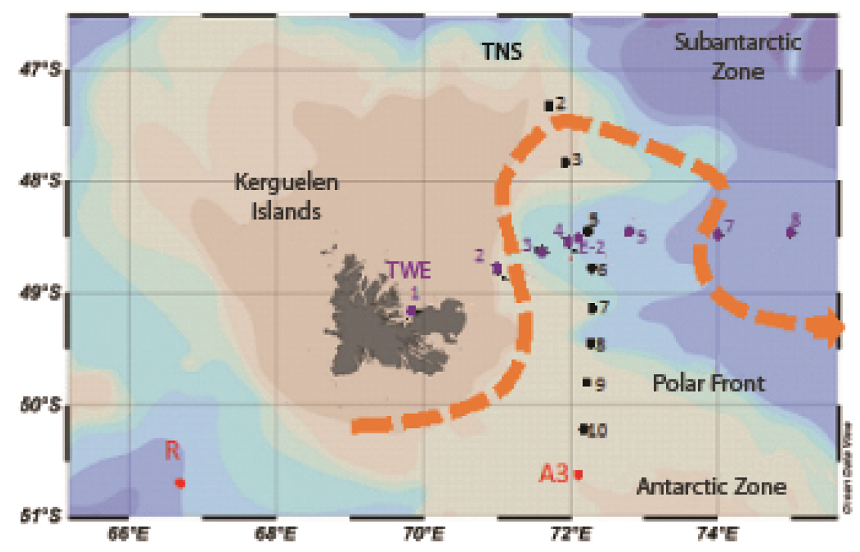

Figure 1. Map showing the location of biogeochemical stations sampled during the KEOPS 2 cruise. Bathymetric topography is shown in the main oceanographic region. The orange line delimits the position of the polar front. The transects are indicated.

\subsection{Sampling}

Continuous vertical profiles of temperature, salinity, dissolved $\mathrm{O}_{2}$, fluorescence and photosynthetically active radiation (PAR) were obtained using a conductivity-temperature- depth (CTD) sensor. Seawater samples were collected using a Sea-Bird SBE 911plus CTD unit mounted on a 24-bottle (12 $\mathrm{L}$ each) rosette. Water samples for gases $\left(\mathrm{N}_{2} \mathrm{O}, \mathrm{CH}_{4}\right)$, nutrients and pigments (sampled in this consecutive order) were obtained from nine depths distributed between the surface and $500 \mathrm{~m}$ depth. Water samples for $\mathrm{CH}_{4}$ (triplicate) and $\mathrm{N}_{2} \mathrm{O}$ (triplicate) analyses were taken in $20 \mathrm{~mL}$ glass vials and poisoned with $\mathrm{HgCl}_{2}\left(0.1 \mathrm{~mL}\right.$ of saturated $\mathrm{HgCl}_{2}$ solution per vial). Subsequently, the vials were sealed with a butyl-rubber septum and an aluminium cap, avoiding bubble formation, and stored in darkness at room temperature until laboratory analysis. Syringes of $50 \mathrm{~mL}$ were directly connected to the spigot of the Niskin bottles to take nutrient samples $\left(\mathrm{NO}_{3}^{-}\right.$, $\mathrm{NO}_{2}^{-}, \mathrm{PO}_{4}^{3-}$ and $\mathrm{H}_{4} \mathrm{SiO}_{4}$ ) at each sampled depth. Duplicate samples were collected and drawn through a $0.45 \mu \mathrm{m}$ Uptidisc adapted to the syringe, and then immediately analysed using an autoanalyser (more details in Blain et al., 2015). Total chlorophyll $a(T \mathrm{Chl} a$ ) samples in triplicate were filtered into a $25 \mathrm{~mm}$ glass-fibre filter (GF/F), and then immediately frozen $\left(-20^{\circ} \mathrm{C}\right)$. Samples were kept until later analysis by high-performance liquid chromatography (HPLC) (more details in Lasbleiz et al., 2014). 


\subsection{Chemical analysis}

$\mathrm{N}_{2} \mathrm{O}$ and $\mathrm{CH}_{4}$ were analysed by generating a $5 \mathrm{~mL}$ ultra-pure helium headspace in a vial using a gastight syringe and then equilibrating the gas and liquid phases at $40^{\circ} \mathrm{C}$ within the vial. Following this the gases within the vial were quantified through the use of a gas chromatograph determined by headspace equilibration $(5 \mathrm{~mL}$ helium headspace and $15 \mathrm{~mL}$ of seawater) at $40^{\circ} \mathrm{C}$. Finally quantification via chromatography was carried out. $\mathrm{N}_{2} \mathrm{O}$ was analysed in a Varian 3380 gas chromatograph using an electron capture detector (ECD) at $350{ }^{\circ} \mathrm{C}$ and connected to an autosampler device. $\mathrm{CH}_{4}$ was analysed in a Shimadzu 17A gas chromatograph using a flame ionization detector (FID) at $250^{\circ} \mathrm{C}$ through a capillary column GS-Q at an oven temperature of $30^{\circ} \mathrm{C}$. A calibration curve was made with four concentrations for $\mathrm{N}_{2} \mathrm{O}(0.1$, $0.32,0.5$ and $1 \mathrm{ppm}$, by Matheson standards) and four concentrations for $\mathrm{CH}_{4}(0.5,1.78,2$ and $10 \mathrm{ppm}$, by Matheson standards). Both detectors linearly responded to these concentration ranges. The analytical error for the $\mathrm{N}_{2} \mathrm{O}$ and $\mathrm{CH}_{4}$ analyses was less than 3 and $5 \%$, respectively. The ECD and FID linearly responded to these concentration ranges, and the analytical error for the $\mathrm{N}_{2} \mathrm{O}$ measurements for this study was about $3 \%$. The uncertainty of the measurements was calculated from the standard deviation of the triplicate measurements by depth. Samples with a variation coefficient higher than $10 \%$ were not taken into account for the gas database.

More details regarding the analysis of both gases can be found in Farias et al. (2009). Nutrients were immediately analysed onboard using standard automated colorimetric methods (Tréguer and LeCorre, 1975) using the continuous flow autoanalyser (Skalar). The precision and detection limit of the method was \pm 50 and $20 \mathrm{nM}$, respectively, for $\mathrm{NO}_{3-}$, and \pm 30 and $110 \mathrm{nM}$ for $\mathrm{PO}_{4}^{-3}$ (more details in Blain et al., 2014). $\mathrm{NH}_{4}^{+}$was measured by means of fluorometric analysis (Holmes et al., 1999) with a precision of $\pm 50 \mathrm{nM}$.

\subsection{Data analysis}

To interpret the vertical variation of $\mathrm{N}_{2} \mathrm{O}$ and $\mathrm{CH}_{4}$, and assess how biogeochemical processes may affect their concentrations, the water column was divided into two layers according to density gradient: (1) well mixed and (2) subsurface from the base of the mixed layer (ML) to $500 \mathrm{~m}$ (arbitrary depth used only for comparison proposes). $\mathrm{Nu}$ trient inventories for $T \mathrm{Chl} a, \mathrm{~N}_{2} \mathrm{O}$ and $\mathrm{CH}_{4}$ were calculated by numerical integration of data with linear interpolation at intervals of $1 \mathrm{~m}$, based on at least 4-6 sampled depths per layer. Saturation percentages of gases were calculated from the measured $\mathrm{CH}_{4}$ and $\mathrm{N}_{2} \mathrm{O}$ concentrations and those estimated to be in equilibrium with the current gas concentrations in the atmosphere register (NOAA/ESRL programme http://www.esrl.noaa.gov/gmd/hats/combined/N2O. $\mathrm{html}$ ) based on in situ temperature and salinity records according to the solubility parameterization of $\mathrm{CH}_{4}$ (Wiesen- burg and Guinasso, 1979) and $\mathrm{N}_{2} \mathrm{O}$ (Weiss and Price, 1980). GHG flux through the air-sea interface was determined using the following equation, modified by Wanninkhof (1992):

$F=\operatorname{kw}\left(T^{\circ}\right.$, salinity $) \cdot\left(C_{\mathrm{w}}-C_{\mathrm{a}}\right)$,

where $\mathrm{kw}$ is the transfer velocity from the ML to the atmosphere, as a function of wind speed, temperature and salinity in the ML according to parameterization; $C_{\mathrm{w}}$ is the mean gas concentration in the mixed layer; and $C_{\mathrm{a}}$ is the gas concentration in the mixed layer expected to be in equilibrium with the atmosphere. Since gas transfer velocity is related to wind speed, this was calculated according to the wellknown exchange models of Liss and Merlivat (1986) (hereafter referred to as LM86) and Wanninkhof (1992) (hereafter referred to as W92), based on the dependence of the transfer velocity on wind speed. Wind speed and direction were obtained from the ship's meteorological station. Wind speed was estimated as a moving 7-day average prior to the sampling period in order to smooth out short-term fluctuations and highlight longer-term trends. The mixed layer depth was calculated using a potential density-based criterion, defining the mixed layer depth (ML) as the shallowest depth at which density increased by $0.02 \mathrm{~kg} \mathrm{~m}^{-3}$ from the sea surface value.

Pearson product-moment correlations (rs) were determined for GHGs, and TChl $a$ and nutrient inventories were estimated for both the ML and for the whole water column from the surface to $500 \mathrm{~m}$ depth. The threshold value for statistical significance was set to $p<0.05$. A principal component analysis (PCA) using the empirical orthogonal function (EOF; Emery and Thomson, 1997) was performed to find the co-variability patterns of a number of stations located in spatial gradients in terms of nutrients, gases $\left(\mathrm{O}_{2}, \mathrm{~N}_{2} \mathrm{O}\right.$, and $\mathrm{CH}_{4}$ ), TChl $a$ and $d \mathrm{Fe}$. This analysis excluded the stations from the TNS as no measurements were recorded (Quéroué et al., 2015). PCA was done with all biogeochemical variables measured in the ML and with those variables obtained in the water column from the surface to a depth of $500 \mathrm{~m}$ in order to detect differences in the vertical structure.

\section{Results}

\subsection{Oceanographic conditions}

Oceanographic characteristics of the sample stations during the KEOPS 2 cruise are shown in Table 1. Two transects, carried out almost synoptically across and along the KPR (survey region - Fig. 1), were undertaken to establish the position of the main mesoscale structures as fronts (Fig. 2). The polar front (PF) crosses the KPR and denotes certain physical structures (i.e. convergence processes) visible throughout temperature and salinity (Park and Vivier, 2012).

Regarding the TEW (66 to $75^{\circ} \mathrm{E}$, along $47^{\circ} \mathrm{S}$ ), vertical cross sections of temperature and salinity along with a temperature-salinity $(T-S)$ diagram are illustrated in Fig. 2a, 
a)
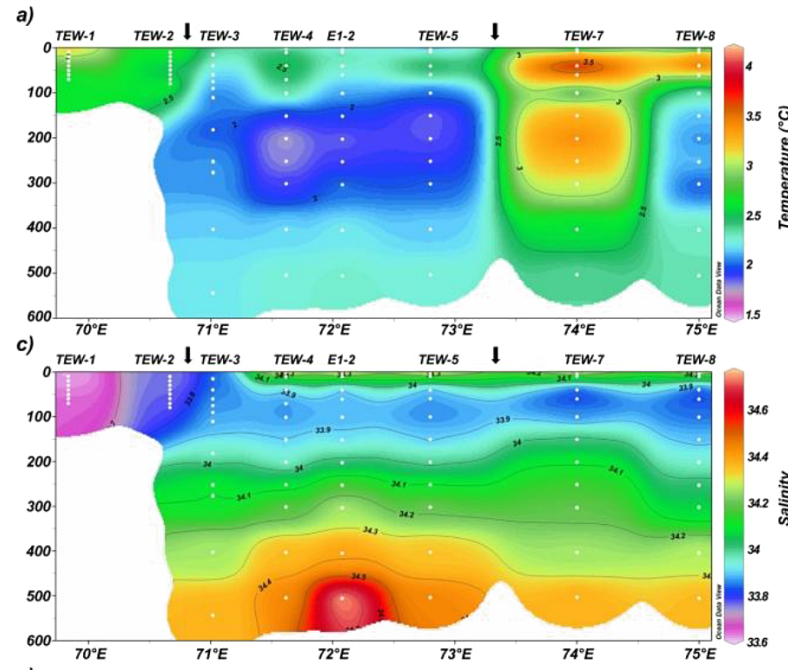

e)

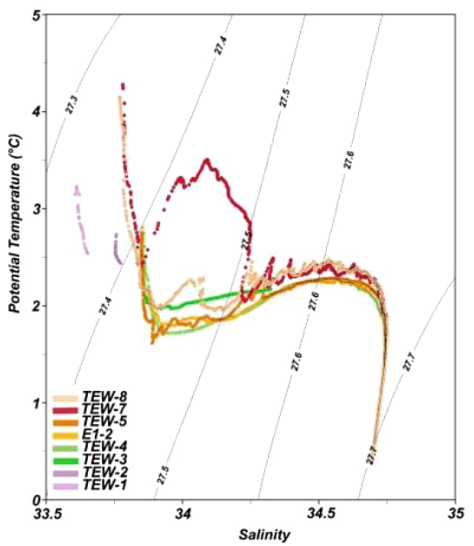

b)
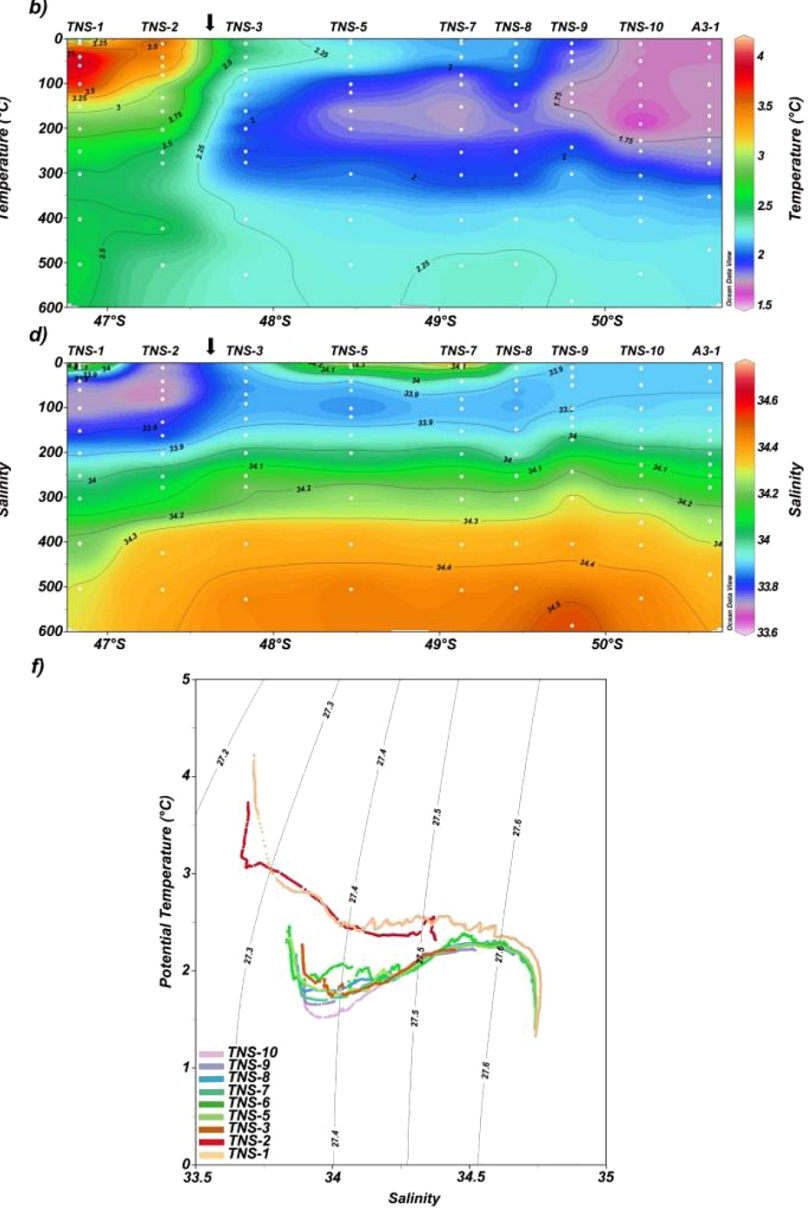

Figure 2. Left column: (a) Temperature $\left(T^{\circ} \mathrm{C}\right)$, (c) salinity and (e) temperature-salinity $(T-S)$ diagram for the TEW. The station located close to the PF (purple) is shown, showing enhanced water mass mixing. Arrows indicate the position of the PF crossing this transect. Right column: (b) temperature $\left(T^{\circ} \mathrm{C}\right)$, (d) salinity and (f) $T-S$ diagram for the TEW.

c and e. Temperature and salinity varied between 2.41 and $3.30^{\circ} \mathrm{C}$ and between 33.60 and 34.67 , respectively. A weak structure with colder and fresher surface waters was registered in the PF, which crossed these transects twice, at $\sim 71^{\circ} \mathrm{E}$ (TEW-3, TEW-4) and at $\sim 73.5^{\circ} \mathrm{E}$ (TEW-7, TEW8). Middle stations (TEW-4, TEW-5 and E) are located in an area with a complex recirculatory system. This is a superficial section inundated by mixed Antarctic Surface Water (AASW) and coinciding with an area of a PF northward inflexion (Fig. 1). The presence of Subantarctic Mode Water (SAMW) was observed east of $73.5^{\circ} \mathrm{E}$ (TEW-7, TEW-8; Fig. 2f). In addition, a marked variability in subsurface water was observed, attributed to the mixing of water masses; this was particularly strong in TEW within the PF, revealing a vertical mixing process produced by convergence, particularly evident at TEW-7 (Fig. 2e). Regarding the TNS $\left(46^{\circ}-51^{\circ} \mathrm{S}\right.$, along $\left.\sim 72^{\circ} \mathrm{E}\right)$, Fig. $2 \mathrm{~b}, \mathrm{~d}$ and $\mathrm{f}$ show vertical cross sections of temperature, salinity and a $T-S$ diagram, respectively. Temperature and salinity fluctuated from 1.67 to $4.17^{\circ} \mathrm{C}$ and from 33.67 to 34.68 , respectively, and a grad- ual decrease in temperature and increase in salinity were observed in the surface layer from north to south (Fig. 2b, d). A water parcel of a relatively cold water mass was observed to be spreading northward in subsurface waters. This is noted as an expression of the PF, which marks the location where the AASW moves northward, descends rapidly, and sinks below $200 \mathrm{~m}$ depth (Fig. 2b). These distributions coincided with the expected water mass distribution, this being the case for the northern (TNS-1, TNS-2) and southern (A3, TNS-10) stations, mainly occupied from the surface to $250 \mathrm{~m}$ by the SAMW and the AASW, respectively (Fig. 2f).

\subsection{Biogeochemical variables}

Figure 3 shows vertical cross sections along the TEW of biogeochemical variables including nutrients (only $\mathrm{NO}_{3}^{-}$and $\mathrm{PO}_{4}^{3-}$ ), $T \mathrm{Chl} a, \mathrm{O}_{2}$ and GHGs. The surface layer continuously showed $\mathrm{NO}_{3}^{-}$concentrations, fluctuating from 22 to $27 \mu \mathrm{mol} \mathrm{L}^{-1}$ (typical condition of the AASW). However, a relative depletion of $\mathrm{NO}_{3}^{-}$was observed at the stations lo- 
a)
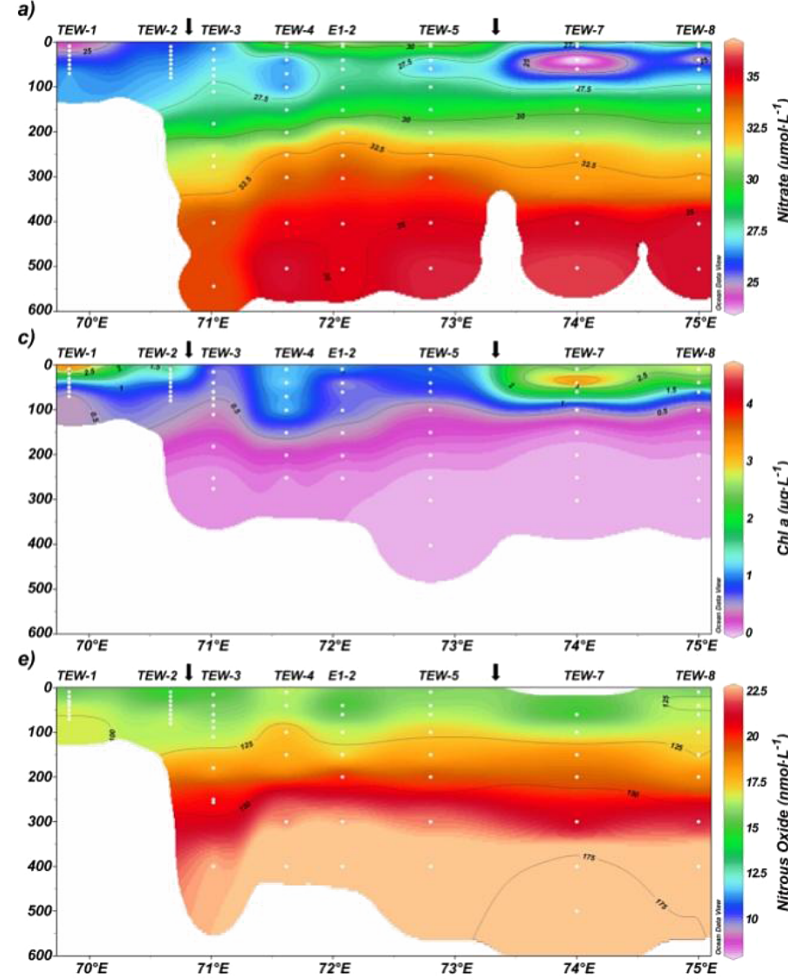
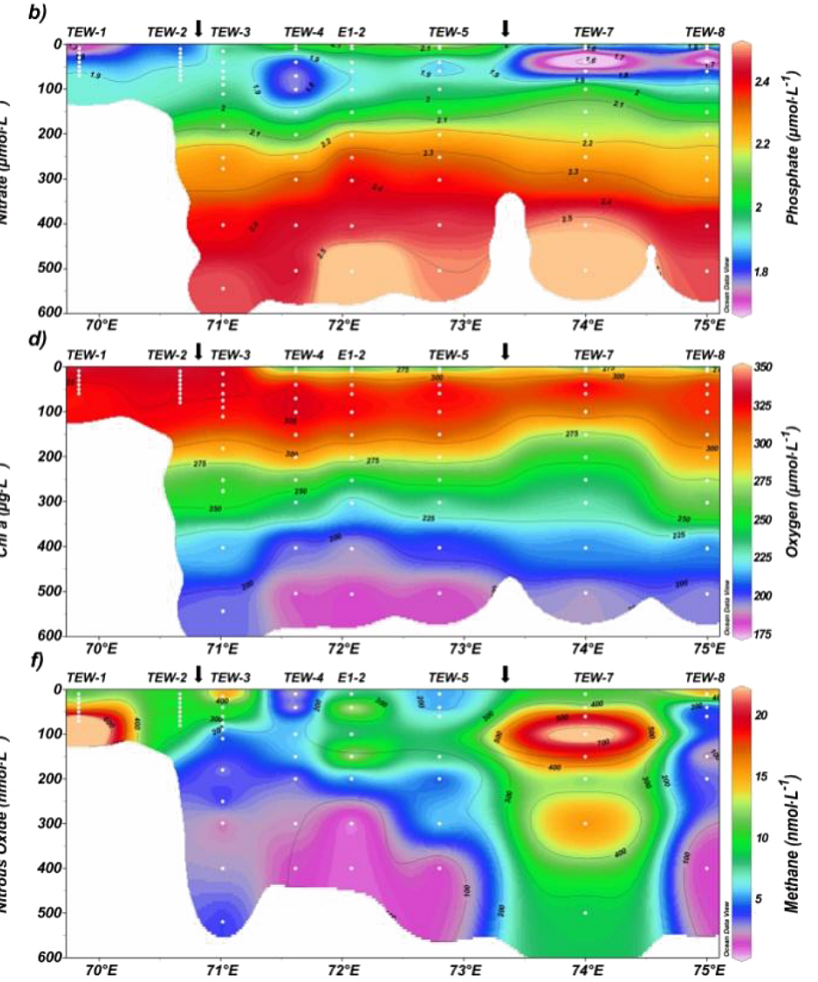

Figure 3. Vertical cross section of (a) nitrate $\left(\mu \mathrm{mol} \mathrm{L}^{-1}\right)$, (b) phosphate $\left(\mu \mathrm{mol} \mathrm{L}^{-1}\right)$; (c) chlorophyll $a\left(\mu \mathrm{g} \mathrm{L}^{-1}\right)$, (d) dissolved oxygen

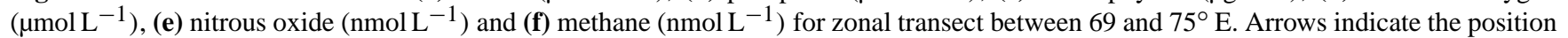
of the PF crossing this transect.

cated to the north and east of the $\mathrm{PF}$ (Fig. 3a). $\mathrm{PO}_{4}^{3-}$ presented the same pattern as $\mathrm{NO}_{3}^{-}$, and the $\mathrm{N}: \mathrm{P}$ ratio of dissolved nutrients averaged around 14.5 , with the exception of some values of 13.2 from stations located close to the PF (Fig. 3b). TChl $a$ fluctuated from 0.005 to $4.69 \mu \mathrm{g} \mathrm{L}{ }^{-1}$ and peaked at TEW-1 and TEW-2 (both located in a coastal area 10 and $75 \mathrm{~km}$ away from Hillsborough Bay coast) as well as TEW-7 and TEW-8 (to the north of the PF). TChl $a$ showed a relative decrease at stations located in the central section (Fig. 3c). $\mathrm{O}_{2}$ concentration varied from $320 \mu \mathrm{M}$ (in surface water) to $185 \mu \mathrm{M}$ (at $500 \mathrm{~m}$ depth), consistently maintaining supersaturation conditions (Fig. 3d).

$\mathrm{N}_{2} \mathrm{O}$ fluctuated from 14.0 to $25.4 \mathrm{nmol} \mathrm{L}^{-1}$ (equivalent to a range of 102-182.2\% saturation, Fig. 3e). Superficially, in the western and central section $\left(70.5-73^{\circ} \mathrm{E}\right)$, the $\mathrm{N}_{2} \mathrm{O}$ concentration was close to equilibrium with the atmosphere in surface waters, and in surface waters at sites where the PF crosses the transect, i.e. TEW-4 and TEW-7 (Fig. 3e) $\mathrm{N}_{2} \mathrm{O}$ was slightly undersaturated (around $90 \%$ ). $\mathrm{N}_{2} \mathrm{O}$ levels increased slightly attaining around $120 \%$ saturation towards the subsurface water. $\mathrm{CH}_{4}$ ranged from 1.4 to $31.35 \mathrm{nmol} \mathrm{L}^{-1}$, equivalent to a saturation range of $43-$ $969 \%$. In contrast to $\mathrm{N}_{2} \mathrm{O}$, surface waters were always supersaturated in $\mathrm{CH}_{4}$, demonstrating the greatest increase in gas levels (up to $970 \%$ ) in coastal waters close to the Kergue- len Islands, a relative decrease $(<200 \%$ saturation) in the central section (between $71^{\circ}$ and $73.5^{\circ} \mathrm{S}$, or TEW-4, TEW5 and E-2), and a strong increase (up to $778 \%$ ) at TEW-7. Remarkably, $\mathrm{CH} 4$ concentrations in subsurface waters were low compared to the surface waters (Fig. 3f).

Vertical cross sections of biogeochemical variables along the TNS are shown in Fig. 4. $\mathrm{NO}_{3}^{-}$and $\mathrm{PO}_{4}^{3-}$ gradually increased from north to south from 24 to $30 \mu \mathrm{mol} \mathrm{L}^{-1}$ and from 1.5 to $2 \mu \mathrm{mol} \mathrm{L}^{-1}$, respectively (Fig. $4 \mathrm{a}, \mathrm{b}$ ). This spatial trend coincided with the expected transition of water mass dominance and its mixing between the SAMW and the AASW (Fig. 2f). TChl $a$ ranged from 0.005 to $2.391 \mu \mathrm{g} \mathrm{L}^{-1}$ and peaked in the southernmost stations (TNS-8, TNS-9 and A32 ; Fig. 4b) and coincided with a slight increase in nutrients. There a deep Fe-enriched and lithogenic silica reservoir seemed to influence the area (Lasbleiz et al., 2014; Quéroué et al., 2015). $\mathrm{O}_{2}$ distribution was similar to that observed in the TEW.

$\mathrm{N}_{2} \mathrm{O}$ concentrations ranged from 12.37 to $23.8 \mathrm{nmol} \mathrm{L}^{-1}$, equivalent to 88.5 to $171 \%$ saturation. $\mathrm{N}_{2} \mathrm{O}$ levels close to equilibrium or undersaturation were often observed in surface waters, except at TNS-08 (Fig. 4e). $\mathrm{CH}_{4}$ varied from 1.47 to $21.88 \mathrm{nM}$, or 45 to $666 \%$ saturation, and peaked in southern stations (Fig. 4f). Notably, high levels of $T \mathrm{Chl} a$ were associated with high concentrations of $\mathrm{CH}_{4}$ in this tran- 

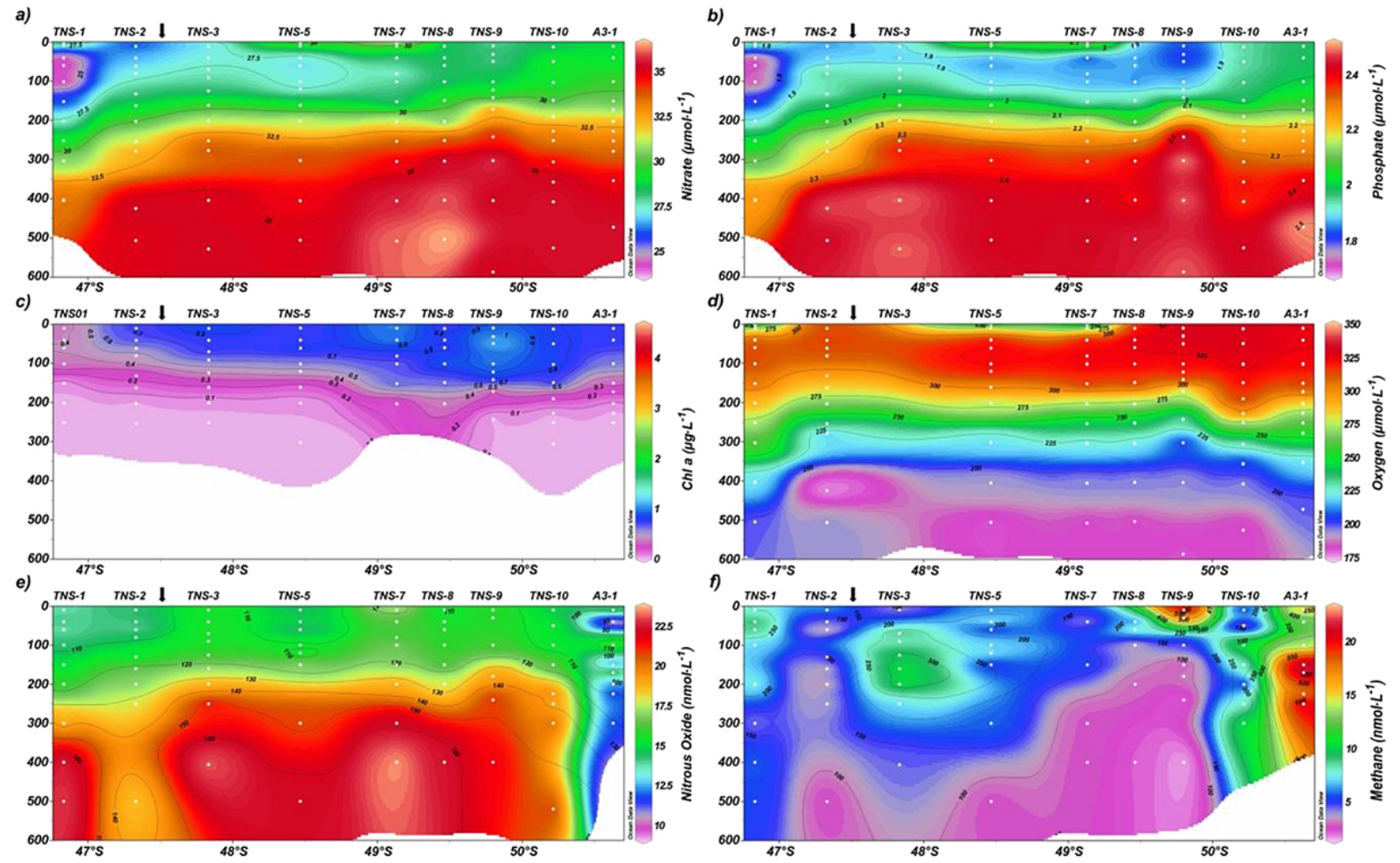

Figure 4. Vertical cross section of (a) nitrate $\left(\mu \mathrm{mol} \mathrm{L}^{-1}\right)$, (b) phosphate $\left(\mu \mathrm{mol} \mathrm{L}^{-1}\right)$, (c) chlorophyll $a\left(\mu \mathrm{g} \mathrm{L}{ }^{-1}\right)$, (d) dissolved oxygen

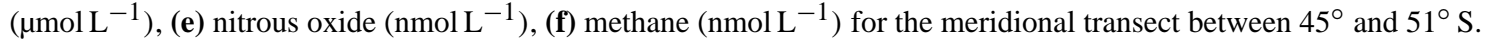

sect. Southern stations had extremely low $\mathrm{N}_{2} \mathrm{O}$ concentrations (less than $6.9 \mathrm{nM}$ or $70 \%$ saturation), such as A3-1, which is located in an area of relatively high $d \mathrm{Fe}$ availability and within a phytoplankton bloom.

PCA was performed including $d \mathrm{Fe}$ and GHG data obtained from the TEW, as shown in Fig. 5. The results did not change when $\mathrm{O}_{2}$ was removed from the analysis, indicating that $\mathrm{O}_{2}$ availability does not modify the percentage of the variance. When the data set used in the PCA is restricted to the ML (Fig. 5a), stations located on the TEW were grouped into three sets, clearly separating stations located in eastern (north of the PF, TEW-7), western, and coastal areas (TEW1, TEW-2), and within the central section (TEW-4, TEW5, E2). The variability among stations can be predominantly explained by the first component, accounting for $75.7 \%$ of the variance. Figure 5 suggests possible interpretations of the relationships between the variables with their respective weights assigned to each of them (illustrated with an eigenvector). The figure shows a close relationship between $\mathrm{N}_{2} \mathrm{O}$, nutrients, $\mathrm{CH}_{4}, d \mathrm{Fe}$ and $T \mathrm{Chl} a$. PCA using data from the entire water column (Fig. 5b) reproduced a similar grouping to those performed with data from surface waters (Fig. 5a).

\subsection{Vertical distribution of gases and other variables at selected stations}

Figure 6 shows typical profiles of oceanographic and biogeochemical variables (including gases). Stations were separated a priori according to biogeochemical (PCA for the case of the TEW; Fig. 5) and oceanographic criteria ( $T$ $S$ diagram, Fig. 2e, f). Selected stations included those of $\mathrm{A} 3$, with a recurrent annual bloom (historical station sampled in KEOPS 1; Blain et al., 2007) and moderate $d$ Fe levels $\left(\sim 0.18 \mathrm{nmol} \mathrm{L}^{-1}\right)$. Some stations displayed evidence of an active uptake of $d \mathrm{Fe}$; TEW-7 had one of the highest $d \mathrm{Fe}$ $\left(\sim 0.40 \mathrm{nmol} \mathrm{L}^{-1}\right)$ and $T \mathrm{Chl} a$ levels, and also showed evidence of rapid $d \mathrm{Fe}$ uptake (Fourquez et al., 2014). For comparative purposes, we include the most northern station of the TNS (TNS-01), R-2 (in the HNLC area), and a coastal station close to the Kerguelen Islands, which had the highest $d \mathrm{Fe}$ levels (up to $3.82 \mathrm{nmol} \mathrm{L}^{-1}$ ). Vertical distribution of $\mathrm{N}_{2} \mathrm{O}$ and $\mathrm{CH}_{4}$ clearly varied, while elevated $\mathrm{CH}_{4}$ concentrations were generally observed superficially and in the ML base, and concentrations decreased with increased depth, whereas $\mathrm{N}_{2} \mathrm{O}$ concentrations gradually increased with depth. Gas contents also differed between stations and were observed to correlate in a similar way with $T \mathrm{Chl} a$ and $d \mathrm{Fe}$ levels.

The stations located at the extremities of the TEW (i.e. TEW-1 and TEW-7) had the highest $\mathrm{CH}_{4}$ levels (Fig. 6), 

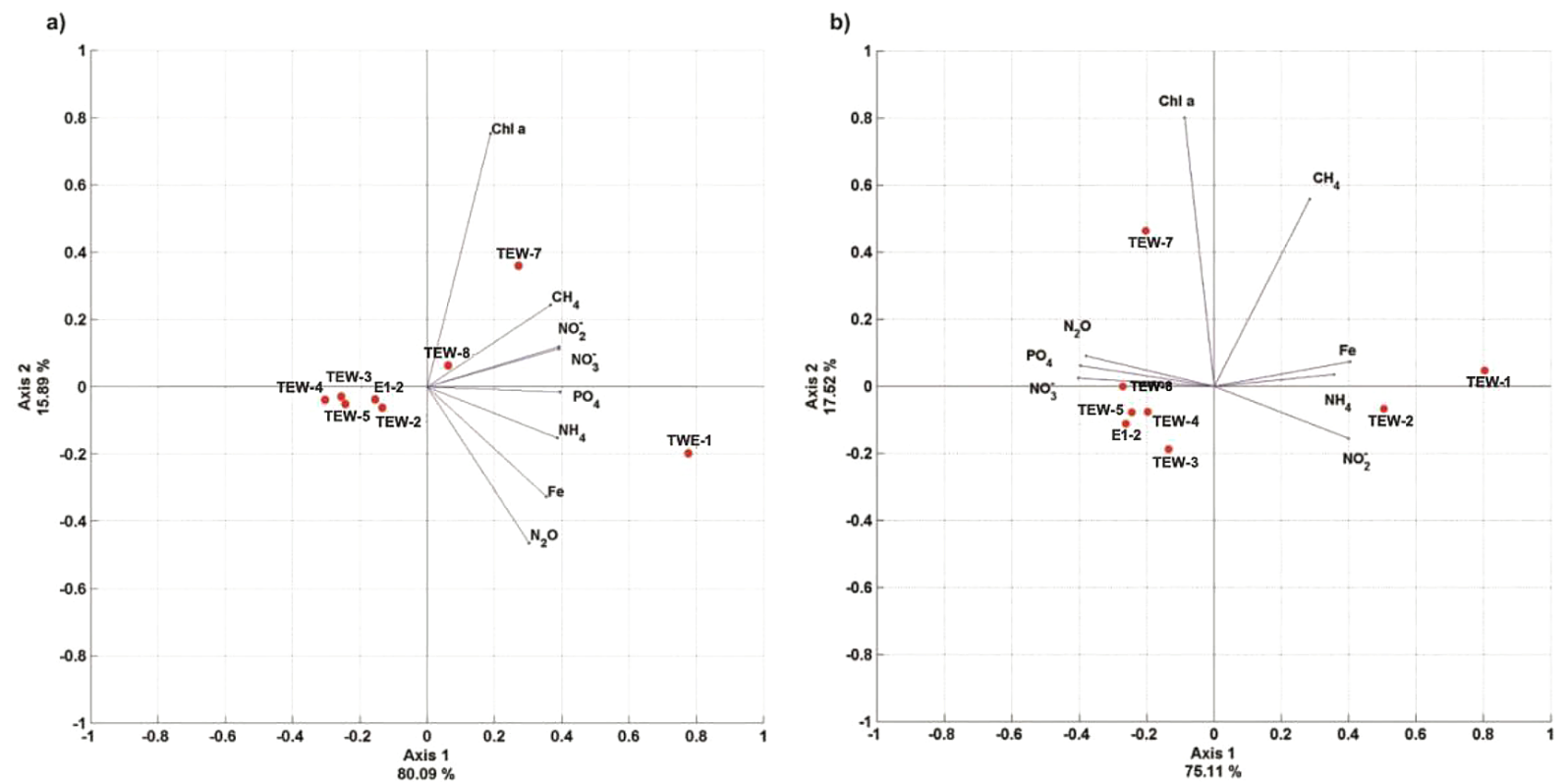

Figure 5. PCA with environmental data including dissolved iron obtained in the zonal transect (TEW). PCA comprises (a) data from the surface to the base of the ML and (b) environmental data from the surface to $500 \mathrm{~m}$ depth. Stations along with the eigenvectors are included.

while $\mathrm{N}_{2} \mathrm{O}$ levels were relatively low. Conversely, TNS-1 and A3-2, located respectively in the extreme north and south of the TNS, presented relatively low levels of $\mathrm{CH}_{4}$ compared to the TEW. Station R-2, which is located in the HNLC area, had the lowest $\mathrm{N}_{2} \mathrm{O}$ and $\mathrm{CH}_{4}$ content, and both gases were homogeneously distributed with depth (Fig. 6). This is consistent with $T \mathrm{Chl} a$ levels of less than $0.5 \mu \mathrm{g} \mathrm{L}^{-1}$.

\subsection{Nutrient, $T \mathrm{Chl} a, d \mathrm{Fe}$, and GHG inventories and air-sea GHG exchanges}

Table 2 shows the inventories of $\mathrm{NO}_{3}, \mathrm{PO}_{4}^{3-}$ and $\mathrm{GHG}$ in the ML and the water column from the surface to $500 \mathrm{~m}$; mean GHG concentrations in the ML, wind speed, and air-sea GHG fluxes are also included. ML depths varied widely from $16 \mathrm{~m}$ (at the station near the Kerguelen Islands) to $181 \mathrm{~m}$. The $T C h l a$ pool, estimated on the basis of the photic layer, fluctuated from 8.77 to $75.45 \mathrm{mg} \mathrm{m}^{-2}$. Levels were notably elevated at A3-2 (up to 5-fold greater), in comparison to the more oligotrophic stations such as R-2. Surface $\mathrm{NO}_{3}^{-}$and $\mathrm{PO}_{4}^{3-}$ inventories did not show significant differences among stations and varied between 1.56 and 16.03 and between 0.13 and $1.07 \mathrm{~mol} \mathrm{~m}^{-2}$, respectively. Minimal values were registered at stations TEW-7-8 and TNS-1, both located north of the PF.

$\mathrm{N}_{2} \mathrm{O}$ pools varied from 0.201 to $2.55 \mathrm{mmol} \mathrm{m}^{-2}$ and from 1.12 to 10.05 in the ML and the whole water column, respectively. Minimum values were registered in the ML at stations within the PF and also to the north. These surface pools did not significantly correlate with $T \mathrm{Chl} a$, but correlated strongly and negatively with nutrients (rs: $0.91 p<0.001$ for
$\mathrm{NO}_{3}^{-}$; rs: 0.92, $p<0.001$ for $\mathrm{PO}_{4}^{3-}$ ). $\mathrm{CH}_{4}$ inventories fluctuated between 0.19 and $3.31 \mathrm{mmol} \mathrm{m}^{-2}$ for the ML, and 1.06 and $7.44 \mathrm{mmol} \mathrm{m}^{-2}$ for the whole water columns. Once again, inventories in the ML were 2- and 5-fold higher at TEW-7 and A3-2, respectively, than at $\mathrm{R}-2 . \mathrm{CH}_{4}$ inventories were 4- and 7-fold higher at TEW-7 and A3-2, respectively, than at R-2. The comparison between the $\mathrm{CH}_{4}$ inventories (standardized by the thickness of the layer) obtained from the ML and from the entire water column indicates that the maximum values came from the ML's base, notably in the PF (Table 2). $\mathrm{CH}_{4}$ pools correlated positively with $T \mathrm{Chl} a$ pools ( $\mathrm{rs}=0.69 ; p<0.05)$ but did not show any correlation with $\mathrm{NO}_{3}^{-}$and $\mathrm{PO}_{4}^{3-}$. Thus, minimum values for both nutrients were found when $T \mathrm{Chl} a$ was higher.

Average hourly wind velocity during the cruise was $10.53 \pm 5.52 \mathrm{~m} \mathrm{~s}^{-1}$, occasionally falling below $0.31 \mathrm{~m} \mathrm{~s}^{-1}$ or rising above $29.1 \mathrm{~m} \mathrm{~s}^{-1}$. The ML depth did not show any significant relationship to wind speed (rs: $0.20 p=0.41$ ) or the water mass structure (Table 1 and Fig. 2) but seems to be related to the complex mesoscale circulation observed in the KPR (Park et al., 2014; Zhou et al., 2014). $\mathrm{N}_{2} \mathrm{O}$ fluxes, estimated by LM86, fluctuated between -9.69 and $10.02 \mu \mathrm{mol} \mathrm{m}^{-2} \mathrm{~d}^{-1}$ (mean: $1.25 \pm 4.04 \mu \mathrm{mol} \mathrm{m}^{-2} \mathrm{~d}^{-1}$ ), while those estimated by W92 varied from -18.69 to $20.2 \mu \mathrm{mol} \mathrm{m}^{-2} \mathrm{~d}^{-1}$ (mean: $2.41 \pm 7.88$ ). Substantial differences were observed between the cubic (LM86) and the quadratic parameterizations (W92) during periods of high wind speeds, such as those measured during the TNS (2123 October 2011 , mean value of $12.08 \mathrm{~m} \mathrm{~s}^{-1}$ ), compared to those registered during the TEW (31 October-2 November, mean value of $5.61 \mathrm{~m} \mathrm{~s}^{-1}$ ). The W92 parameterization 

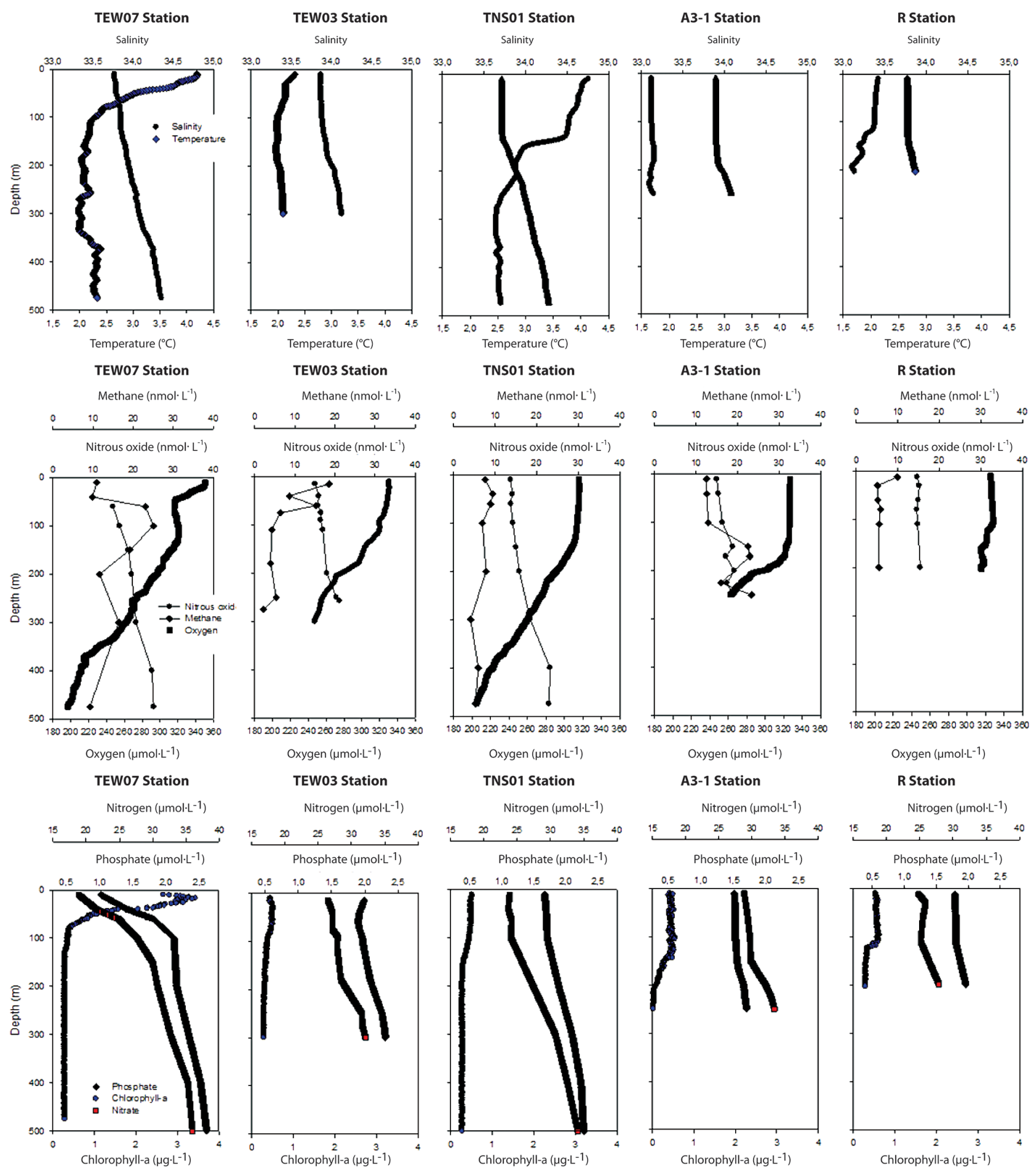

Figure 6. Vertical distribution of biogeochemical variables from selected stations. Different biogeochemical regimes are defined as HNLC area $(\mathrm{R})$, northern and southern area of the polar front (TNS-1 and A3-2) and close to the polar front (TEW-3 and TEW-7). 
Table 2. Inventories of gases and nutrients estimated in the mixed layer (ML) and the entire water column, along with GHG concentrations, wind velocities and concomitant estimated gas exchange across the air-sea interface.

\begin{tabular}{|c|c|c|c|c|c|c|c|c|c|c|c|c|c|c|c|c|}
\hline \multirow[t]{2}{*}{ Station } & \multicolumn{5}{|c|}{ Inventory in the ML } & \multicolumn{4}{|c|}{ Inventory in the water column } & \multicolumn{2}{|c|}{ GHGs } & \multirow{2}{*}{$\begin{array}{l}\text { Wind } \\
\mathrm{m} \mathrm{s}^{-1}\end{array}$} & \multicolumn{2}{|c|}{ Flux LM86 } & \multicolumn{2}{|c|}{ Flux W92 } \\
\hline & $\begin{array}{r}\mathrm{Chl} a^{*} \\
\mathrm{mg} \mathrm{m}^{-2}\end{array}$ & $\begin{array}{r}\mathrm{CH}_{4} \\
\mathrm{mmol} \mathrm{m}^{-2}\end{array}$ & $\begin{array}{r}\mathrm{N}_{2} \mathrm{O} \\
\mathrm{mmol} \mathrm{m}^{-2}\end{array}$ & $\begin{array}{r}\mathrm{NO}_{3}^{-} \\
\mathrm{mol} \mathrm{m}^{-2}\end{array}$ & $\begin{array}{r}\mathrm{PO}_{4}^{3-} \\
\mathrm{mol} \mathrm{m}^{-2}\end{array}$ & $\begin{array}{r}\mathrm{N}_{2} \mathrm{O} \\
\mathrm{mmol} \mathrm{m}^{-2}\end{array}$ & $\begin{array}{r}\mathrm{CH}_{4} \\
\mathrm{mmol} \mathrm{m}^{-2}\end{array}$ & $\begin{array}{r}\mathrm{NO}_{3-}^{-} \\
\mathrm{mol} \mathrm{m}^{-2}\end{array}$ & $\begin{array}{r}\mathrm{PO}_{4}^{3-} \\
\mathrm{mol} \mathrm{m}^{-2}\end{array}$ & $\begin{array}{r}\mathrm{N}_{2} \mathrm{O} \\
\mathrm{nM}\end{array}$ & $\begin{array}{r}\mathrm{CH}_{4} \\
\mathrm{nM}\end{array}$ & & $\begin{array}{c}\mathrm{N}_{2} \mathrm{O} \\
\mu \mathrm{mol} \mathrm{m}^{-}\end{array}$ & $\begin{array}{r}\mathrm{CH}_{4} \\
-2 \mathrm{~d}^{-1}\end{array}$ & $\begin{array}{c}\mathrm{N}_{2} \mathrm{O} \\
\mu \mathrm{mol} \mathrm{m}^{-}\end{array}$ & $\begin{array}{r}\mathrm{CH}_{4} \\
-2 \mathrm{~d}^{-1}\end{array}$ \\
\hline \multicolumn{17}{|c|}{$\mathrm{N}-\mathrm{S}$ transect } \\
\hline A3-1 & 12.60 & 3.00 & 2.43 & 5.41 & 0.293 & 5.72 & 4.12 & 7.342 & 0.940 & 13.73 & 6.56 & 6.58 & -1.54 & 18.75 & -2.96 & 35.93 \\
\hline A3-2 & 35.48 & 3.31 & 1.81 & 4.38 & 0.300 & 5.273 & 3.31 & 15.04 & 1.024 & 11.64 & 8,37 & 11.39 & -10.5 & 14.24 & -22.9 & 29.70 \\
\hline TNS-10 & 14.09 & 1.39 & 2.56 & 4.79 & 0.319 & 9.29 & 2.17 & 16.03 & 1.077 & 15.49 & 7.79 & 12.66 & 3.57 & 14.90 & 6.56 & 27.48 \\
\hline TNS-9 & 35.58 & 1.33 & 2.23 & 3.91 & 0.254 & 7.51 & 1.87 & 12.53 & 0.864 & 15.89 & 14.54 & 14.38 & 5.08 & 38.10 & 9.36 & 70.26 \\
\hline TNS-8 & 23.23 & 0.68 & 2.16 & 3.98 & 0.260 & 9.27 & 1.58 & 15.75 & 1.038 & 15.46 & 5.65 & 11.89 & 4.29 & 7.80 & 7.92 & 14.38 \\
\hline TNS-7 & 25.45 & 0.25 & 1.02 & 1.69 & 0.111 & 9.99 & 1.80 & 15.74 & 1.072 & 16.92 & 4.01 & 11.89 & 8.65 & 2.03 & 15.55 & 3.66 \\
\hline TNS-6 & 16.33 & 0.57 & 0.92 & 1.83 & 0.123 & 8.65 & 2.54 & 15.93 & 1.070 & 13.81 & 8.74 & 11.89 & -0.78 & 17.59 & -1.20 & 31.64 \\
\hline TNS-5 & 17.19 & 0.74 & 1.68 & 3.07 & 0.212 & 9.27 & 2.46 & 15.39 & 1.070 & 14.67 & 6.41 & 11.40 & 1.81 & 9.91 & 3.26 & 17.82 \\
\hline TNS-3 & 17.28 & 0.88 & 1.75 & 3.06 & 0.214 & 7.75 & 3.14 & 12.46 & 0.875 & 11.05 & 7.23 & 11.40 & 4.13 & 9.93 & 6.85 & 16.44 \\
\hline TNS-2 & 11.25 & 0.26 & 0.91 & 1.73 & 0.123 & 8.27 & 1.57 & 15.08 & 1.046 & 13.92 & 4.38 & 9.73 & 1.48 & 3.03 & 2.45 & 5.00 \\
\hline TNS-1 & 11.21 & 0.39 & 0.63 & 1.07 & 0.076 & 8.89 & 3.16 & 14.17 & 0.976 & 13.95 & 8.48 & 9.73 & 2.26 & 14.40 & 3.74 & 23.84 \\
\hline $\mathrm{R}-2$ & 14.89 & 0.64 & 1.63 & 2.79 & 0.197 & 2.83 & 1.06 & 4.900 & 0.347 & 14.83 & 6.29 & 6.86 & 0.89 & 4.09 & 1.34 & 6.15 \\
\hline \multicolumn{17}{|c|}{ W-E transect } \\
\hline TEW-1 & 9.78 & 0.19 & 0.26 & 3.40 & 0.412 & 1.18 & 1.30 & 1.560 & 0.111 & 15.29 & 9.50 & 4.60 & 0.87 & 3.15 & 1.69 & 6.15 \\
\hline TEW-2 & 9.87 & 0.43 & 0.62 & 0.84 & 1.073 & 1.12 & 1.74 & 1.873 & 0.133 & 15.03 & 9.88 & 4.60 & 0.54 & 3.24 & 1.06 & 6.33 \\
\hline TEW-3 & 8.77 & 0.73 & 0.91 & 0.51 & 1.566 & 7.41 & 2.40 & 14.97 & 1.072 & 15.56 & 14.09 & 4.60 & 0.67 & 5.25 & 1.32 & 10.24 \\
\hline E-2 & 15.33 & 0.52 & 0.20 & 0.82 & 1.167 & 9.78 & 2.80 & 15.24 & 1.051 & 14.95 & 11.42 & 6.92 & 1.34 & 11.67 & 2.01 & 17.57 \\
\hline TEW-4 & 35.53 & 0.40 & 1.63 & 0.30 & 2.468 & 10.3 & 1.81 & 15.74 & 1.106 & 16.62 & 3.50 & 6.92 & 3.76 & 0.21 & 5.67 & 0.32 \\
\hline TEW-5 & 23.11 & 0.38 & 0.99 & 0.52 & 1.619 & 10.21 & 2.61 & 15.62 & 1.099 & 16.31 & 6.35 & 6.92 & 3.28 & 4.34 & 4.94 & 6.54 \\
\hline TEW-7 & 75.45 & 0.19 & 0.23 & 2.39 & 0.353 & 9.26 & 7.44 & 15.23 & 1.087 & 12.90 & 10.87 & 8.04 & -0.96 & 15.42 & -1.52 & 23.78 \\
\hline TEW-8 & 59.52 & 0.10 & 0.37 & 1.52 & 0.472 & 10.05 & 1.59 & 15.27 & 1.058 & 15.77 & 4.95 & 8.04 & 5.25 & 3.52 & 8.10 & 5.42 \\
\hline
\end{tabular}

* Inventories estimated from the photic zone.

showed an increase in calculated fluxes by approximately a factor of 2 at high wind speeds, while at low wind speeds the difference between LM86 and W92 was up to a factor of $\sim 1.6$ higher (see Table 2). $\mathrm{CH}_{4}$ fluxes varied from 0.21 to $38.1 \mu \mathrm{mol} \mathrm{m}{ }^{-2} \mathrm{~d}^{-1}$ (mean: $10.01 \pm 9.97$ ) and from 0.32 to $70.24 \mu \mathrm{mol} \mathrm{m}{ }^{-2} \mathrm{~d}^{-1}$ (mean: $21.27 \pm 21.07$ ) when LM86 and W92 were employed, respectively. At times the study area acted as a source of very high $\mathrm{CH}_{4}$ effluxes into the atmosphere, particularly at stations TNS-9 and A3-2, where emissions were around 3 times as high compared to those calculated for R-2. There are important differences between the two parameterizations, although the same trend was obtained among stations (Table 2).

\section{Discussion}

Iron fertilization in the KPR influences phytoplankton growth and primary production (PP) and other microbial activities (Cavagna et al., 2014; Christaki et al., 2014), as well as relative $\mathrm{CH}_{4}$ accumulation (Fig. $3 \mathrm{f}$ and $4 \mathrm{f}$ ) and some $\mathrm{N}_{2} \mathrm{O}$ depletion (Fig. 3e). The gas distribution pattern clearly matched those patterns in Quéroué et al. (2014) for $T$ Chl $a$ and PCA grouped stations using $d \mathrm{Fe}$. The segregation of stations includes the coastal area (TEW-1, TEW-2), the PF (TEW-7) and the central plateau region (A3-2). In the case of KEOPS 2, phytoplanktonic blooms were mainly represented by a microplanktonic community (Lasbeiz et al., 2014), as those observed in the north polar front (TEW-7) and the central part of the KPR (A3) stations displayed high rates of iron uptake (Quéroué et al., 2014). These previously indi- cated areas demonstrated variable but high particulate Fe of biogenic origin (Van der Merwe et al., 2015). This confirms an increased biological uptake, which in turn determines a rapid $d \mathrm{Fe}$ turnover. The observed gas distribution patterns raise questions as to how the complex circulation and some mesoscale structures support relatively high $T \mathrm{Chl} a$ accumulation and microbial activities in comparison to surrounding waters, and particularly whether there are some fertilization mechanisms (including the addition of $\mathrm{Fe}$ and nutrients) that promote GHG cycling and its associated microbial activities.

\section{1 $\mathrm{N}_{2} \mathrm{O}$ cycling}

Fuhrman and Capone (1991) pointed out that the stimulation of ocean productivity through the addition of $\mathrm{Fe}$ enhances nitrogen export from the euphotic zone to the subsurface layer and may result in enhanced $\mathrm{N}_{2} \mathrm{O}$ formation via the stimulation of nitrification. This stimulation may occur through the activation of metallo-proteins that are involved in the various stages of ammonium and nitrite oxidation, as ammoniaoxidizing nitrifiers oxidize $\mathrm{NH}_{4}^{+}$and $\mathrm{NH}_{2} \mathrm{OH}$ to $\mathrm{NO}_{2}^{-}$using iron-containing ammonia monooxygenase (AMO) and hydroxylamine oxidoreductase (HAO), respectively (Morel et al., 2003). Since $\mathrm{N}_{2} \mathrm{O}$ is a powerful greenhouse gas, 300 times more radiative than $\mathrm{CO}_{2}$ per molecule, $\mathrm{Fe}$ addition could counteract the climatic benefits of atmospheric $\mathrm{CO}_{2}$ drawdown (Jain et al., 2000). The link between Fe fertilization and enhanced $\mathrm{N}_{2} \mathrm{O}$ formation via nitrification was supported by Law and Ling (2001), who found a small but significant $\mathrm{N}_{2} \mathrm{O}$ accumulation in the pycnocline during the Southern Ocean Iron Enrichment Experiment (SOIREE) at 
$61^{\circ} \mathrm{S}, 140^{\circ} \mathrm{E}$. Jin and Gruber (2003) subsequently predicted the long-term effect of Fe fertilization on global oceanic $\mathrm{N}_{2} \mathrm{O}$ emissions using a coupled physical-biogeochemical model. Based on the model outputs, it was concluded that Fe fertilization induced $\mathrm{N}_{2} \mathrm{O}$ emissions that could offset the radiative benefits of the $\mathrm{CO}_{2}$ drawdown. However, during other Southern Ocean iron enrichment experiments (such as EIFEX), Walter et al. (2005) found no $\mathrm{N}_{2} \mathrm{O}$ enrichment after artificial Fe fertilization.

Our findings revealed that natural $\mathrm{Fe}$ fertilization did not appear to stimulate $\mathrm{N}_{2} \mathrm{O}$ accumulation in the superficial layer (within the ML). There was no significant difference in the $\mathrm{N}_{2} \mathrm{O}$ inventory estimates from areas of higher accumulation of biomass with respect to those estimated for R-2, which was used as a reference station (Table 2). Contrary to what was expected, no increase in $\mathrm{N}_{2} \mathrm{O}$ content was observed at stations close to the Kerguelen Islands (TEW-1, TEW-2), which are highly enriched with $d \mathrm{Fe}$ from fresh water and sediments (Quéroué et al., 2014). This trend suggests that nitrifiers in surface water are not being significantly stimulated by $d \mathrm{Fe}$ supply from the sediments. In subsurface water (below ML to $500 \mathrm{~m}$ depth) $\mathrm{N}_{2} \mathrm{O}$ accumulation may be associated with nitrification, and it is noted that nitrate dual isotopic composition $\left(\delta^{15} \mathrm{~N}-\mathrm{NO}_{3}^{-}\right.$and $\left.\delta^{18} \mathrm{O}-\mathrm{NO}_{3}^{-}\right)$revealed an increase in both isotope values with greater water depth in subsurface waters $(100-400 \mathrm{~m})$. This is a result of the partial consumption of available nitrate in surface waters, the export of low $\delta^{15} \mathrm{~N}$ in particulate nitrogen (PN) and the remineralization-nitrification that occurs in this situation (Dehairs et al., 2014). However, values of $\delta^{15} \mathrm{~N}-\mathrm{NO}_{3}^{-}$and $\delta^{18} \mathrm{O}-\mathrm{NO}_{3}^{-}$in surface waters also suggest that nitrification is also occurring in surface waters, but with considerable variation.

Notably, the TEW-7, TEW-8 and A3-2 were observed to be in equilibrium and slightly depleted in $\mathrm{N}_{2} \mathrm{O}$ (Fig. 3e; Table 2). It is likely that the explanation for this would be that the mixing process produced at the $\mathrm{PF}$ (TEW-7) (with moderate levels of Fe, high levels of $T \mathrm{Chl} a$ and evidence of active Fe uptake) may stimulate the $\mathrm{N}$ fixers, as demonstrated by Mills et al. (2004), Berman-Frank et al. (2007) and Moore et al. (2009). N-fixing microorganisms may have an effect on the $\mathrm{N}_{2} \mathrm{O}$ inventory as they could be used as an alternate substrate for fixers, as suggested by Farias et al. (2013). Thus, biological $\mathrm{N}_{2} \mathrm{O}$ fixation could be using and assimilating $\mathrm{N}_{2} \mathrm{O}$, causing $\mathrm{N}_{2} \mathrm{O}$ depletion and a simultaneous undersaturation. $\mathrm{N}$ fixation has been observed in the cold waters of the Arctic and Antarctic (Blais et al., 2012; Diez et al., 2012; Diez, unpublished data), as well as in cold upwelled water (Fernandez et al., 2011), suggesting that $\mathrm{N}_{2} \mathrm{O}$ fixation may also occur more commonly than originally expected. Coincidently, TEW-7 (within the PF) also had the highest surface $\mathrm{N}$ fixation (Gonzalez et al., 2014), suggesting that $\mathrm{N}_{2} \mathrm{O}$ is used as a substrate by diazotrophs (Farias et al., 2013) and that this process is stimulated by enhanced $\mathrm{Fe}$ supply. $\mathrm{N}_{2} \mathrm{O}$ undersat- uration or equilibrium with the atmosphere was observed in the TNS (Fig. 4e), particularly at stations north of the PF with influence from the SAMW. This suggests that some kind of process is occurring that removes or consumes gas from the upper water column. A notable level of undersaturation was also observed at A3-2, which is located in the recurring phytoplankton bloom and within a system of relatively high $d \mathrm{Fe}$ concentration due to the presence of the plateau (Blain et al., 2007).

$\mathrm{N}_{2} \mathrm{O}$ undersaturation has been reported, although rarely, in polar and sub-polar ocean regions (Butler et al., 1989; Law and Ling, 2001; Foster et al., 2009). Physical processes related to gas solubility and deviations from the atmospheric equilibrium gas concentration could not explain the observed undersaturation. If the physical variables alter faster than what is expected for gas equilibrium with the atmosphere, it is probable that there may be a gas deficit. Thus, deviation from the equilibrium condition could be caused by rapid heating or cooling, refreshing, and/or a mixing of water masses (Sarmiento and Gruber, 2006). An analysis of these potential changes was made for the AASW and the SAMW. A cooling (decreasing $T^{\circ} \mathrm{C}>3$ ) or fresh water influence (decreasing salinity from 34 to 10 ) would be required to produce the observed undersaturation, neither of which was observed during the sampling (Table 1) or expected during this season (Park et al., 2014). Additionally, if the two water masses were mixed proportionally, as they are, the resulting process cannot produce undersaturation in regard to the original $\mathrm{N}_{2} \mathrm{O}$ levels and the signature temperature and salinity. Recently, Chen et al. (2014) reported that surface waters of the Indian sector of the Southern Ocean were undersaturated in $\mathrm{N}_{2} \mathrm{O}$, suggesting a $\mathrm{N}_{2} \mathrm{O}$ influx. This phenomenon in the surface water may result from the intrusion of freshwater from ice melt and the northeastward transport of the AASW. However, in the KPR, $\mathrm{N}_{2} \mathrm{O}$ undersaturation seems to be located in an area of high particle concentration under the influence of the SAMW (northern the PF).

Thus, a preliminary analysis indicates that biological processes are responsible for the $\mathrm{N}_{2} \mathrm{O}$ undersaturation and the concomitant influx from the atmosphere. In contrast, subsurface waters have higher $\mathrm{N}_{2} \mathrm{O}$ concentrations (saturations from 120 to $180 \%$ ) than surface waters, which indicate a net accumulation. In this case the most likely process responsible for $\mathrm{N}_{2} \mathrm{O}$ accumulation is aerobic ammonium oxidation (Codispoti et al., 2001), but no significant difference was noted at the stations with the highest $T \mathrm{Chl} a$ levels, indicating that $\mathrm{N}_{2} \mathrm{O}$ production by nitrification was not substantially stimulated at those stations.

\section{2 $\quad \mathrm{CH}_{4}$ cycling}

There have been few studies on $\mathrm{CH}_{4}$ distribution and production in the Southern Ocean (Lamontage et al., 1973; Tilbrook and Karl, 1994; Heeschen et al., 2004). Surface water in the Southern Ocean has been reported to be undersaturated or 
lightly saturated with respect to atmospheric $\mathrm{CH}_{4}$, as a result of the entrainment of $\mathrm{CH}_{4}$-depleted deep water into surface water and the seasonal ice covers acting as a barrier against gas exchange (Yoshida et al., 2011). Regarding the effect of iron addition on $\mathrm{CH}_{4}$ cycling, Wingenter et al. (2004) found low levels of $\mathrm{CH}_{4}$ production (less than $1 \%$ ) during artificial Southern Ocean Fe enrichment experiments (SOFex). Simulated large-scale Southern Ocean Fe fertilization (OIF) also resulted in anoxic conditions which may favour anaerobic methanogenesis (Oschlies et al., 2010).

However, our results show that surface and subsurface waters are supersaturated in $\mathrm{CH}_{4}$ with a 4-fold enrichment in $\mathrm{CH}_{4}$ with respect to the control area (Fig. 3e); this was associated with areas with elevated $T \mathrm{Chl} a$ levels and iron uptake by microbial communities (Fourquez et al., 2014). Results showed a marked spatial differences in $\mathrm{CH}_{4}$ content measured in the TEW and TNS (Student's $t: 3.21 p<0.001$ ) (Fig. 3f and 4f), and that surface $\mathrm{CH}_{4}$ accumulation generally coincided with areas of relatively higher $d \mathrm{Fe}$ levels, which in turn favours primary production (PP). Likewise, the $\mathrm{CH}_{4}$ accumulation at pycnoclines (Fig. 6) indicates that most $\mathrm{CH}_{4}$ came from accumulated particles sinking from the surface water, as commonly observed by Holmes et al. (2000) in different marine systems. PCA, which included the measurement of $d \mathrm{Fe}$, revealed a close relationship between $\mathrm{CH}_{4}$ accumulation and $\mathrm{Fe}$ availability and clearly grouped in areas with different biogeochemical characteristics. The fact that the western and eastern sections showed high Fe levels (Quéroué et al., 2014) relative to the central section of the TEW, and that these sections had high $\mathrm{CH}_{4}$ levels, suggests that $\mathrm{Fe}$ stimulates $\mathrm{CH}_{4}$ production. A similar situation occurs at the $\mathrm{A} 3$ stations with high $T \mathrm{Chl} a$ levels and PP rates, as shown by Cavagna et al. (2014). For example, A3-2 and TEW-7 (maximum TChl $a$ ) had the highest integrated primary production rates (up to $3380 \mathrm{mg} \mathrm{m}^{-2} \mathrm{~d}^{-1}$ ) and the lowest $\mathrm{C}$ export level of around 2-3\% (Cavagna et al., 2014); this suggests an intense level of PP supported by regenerated $\mathrm{N}$ sources. The situation observed at stations TEW-7 and A3-2 contrasted with that observed at R-2 with with the lowest rate of regenerated production (with a PP rate of around $135 \mathrm{mg} \mathrm{m}^{-3} \mathrm{~d}^{-1}$ and an exported $\mathrm{C}$ rate of around $25 \%$ of $\mathrm{PP})$.

Two hypotheses exist for $\mathrm{CH}_{4}$ production in surface waters. The first is that production only occurs in association with anoxic particles (Karl and Tilbrook, 1994), produced for the most part by grazing zooplankton, as methanogenic bacteria were considered to be present in an anaerobic microenvironment in organic particles (pellets) or in the guts of zooplankton (Alldredge and Cohen, 1987; Karl and Tilbrook, 1994). The other hypothesis formulated more recently is that phytoplankton blooms should favour zooplankton grazing process and/or stimulate bacterioplankton activity as $\mathrm{CH}_{4}$ is generated via the degradation of organic methyl compounds by bacteria (Karl et al., 2008).
Increased grazing of microbes by microzooplankton, as observed by Christaki et al. (2014), may contribute to particle recycling (rich in organic carbon and DMSP) and increase the potential for methanogenesis (Weller et al., 2013). Yoshida et al. (2011) found that high $\mathrm{CH}_{4}$ production in the Southern Ocean probably resulted from the grazing processes of Antarctic krill and/or from zooplankton that feed on phytoplankton and the subsequent microbial methanogenesis. This agrees with the findings for sites enriched with iron and biomass that exhibit high carbon fluxes at $100 \mathrm{~m}$ depth, dominated by large faecal pellets rather than phytodetrital aggregates (Laurenceau-Cornet et al., 2015).

Conversely, aerobic $\mathrm{CH}_{4}$ production in the water column could be associated with heterotrophic activities. Christaki et al. (2014) showed that the highest bacterial production rates (up to $110 \mathrm{mg} \mathrm{C}^{-2} \mathrm{~d}^{-1}$ ) and the greatest abundance of heterotrophic bacteria were associated with stations where the phytoplankton bloom was developed (TEW-7 and A32). Recent evidence indicates that methylotrophs are candidates for mediated $\mathrm{CH}_{4}$ generation using methylated compounds such as DMSP and DMS (Florez-Leiva et al., 2013; Weller et al., 2013). Among these heterotrophic microorganisms DMS degradation can be ascribed to methylotrophic bacteria (Vissher et al., 1994) that derive energy from the conversion of methyl into other products, as well as using $\mathrm{S}$ as a source of methionine biosynthesis (Kiene et al., 1999). Current studies of natural and cultivated SAR11 alphaproteobacteria (strain Ca. P. ubique HTCC1062; Sun et al., 2011) indicate that these microorganisms, among the most abundant heterotrophic bacteria in surface waters, possess genes that are encoded for oxidation pathways of a variety of $\mathrm{C} 1$ compounds and that they have the capacity for demethylation and $\mathrm{C} 1$ oxidation but do not incorporate $\mathrm{C} 1$ compounds as biomass. This suggests that there is a close relationship between phytoplankton, the only producers of DMSP (Yoch, 2002), and microbial communities which may be recycling DMS. Phyto- and bacterioplankton relationships control DMS turnover, which could result in several mechanisms of DMSP/DMS degradation (Simó et al., 2002; VilaCosta et al., 2006) and produce $\mathrm{CH}_{4}$ (Damm et al., 2010; Florez-Leiva et al., 2013; Weller et al., 2013). These publications show that phytoplankton species composition and biomass in different bloom phases, as well as eddy dynamics, were important determinants of $\mathrm{CH}_{4}$ saturation and emission.

With regard to the distribution, vertical profiles of the gas indicate that most $\mathrm{CH}_{4}$ is being formed at the surface and pycnoclines (at the base of the ML) and consumed at subsurface and intermediary depths (Fig. 6). Thus, $\mathrm{CH}_{4}$ distribution appears to be controlled largely by biological mechanisms rather than by mixing, contrary to what has been reported by Heeschen et al. (2004). In general, surface waters of the Southern Ocean were undersaturated with respect to atmospheric $\mathrm{CH}_{4}$ as the result of the entrainment of $\mathrm{CH}_{4}$-depleted deep water to the surface and from seasonal ice cover acting as a barrier for gas exchange. We observed $\mathrm{CH}_{4}$ undersatura- 
tion, fluctuating between 40 and $90 \%$, at most sampled stations at depths of $>200 \mathrm{~m}$. It is unlikely that this undersaturation results from the entrainment of $\mathrm{CH}_{4}$-depleted waters that have high levels of gas solubility; more likely, it results from a biological consumption, as it is more likely that a biological mechanism is involved. The only known process able to consume $\mathrm{CH}_{4}$ is methanotrophy, and the fact that subsurface waters were depleted of $\mathrm{CH}_{4}$ suggests that $\mathrm{CH}_{4}$ consumption is higher than production or that no production occurs in subsurface waters. Interestingly, although $\mathrm{CH}_{4}$ microbial oxidation occurs throughout the water column and is recognized as an important process that reduces $\mathrm{CH}_{4}$ emissions (Reeburgh et al., 2007; Rehder et al., 1999), there have been few investigations on microbial communities mediating aerobic $\mathrm{CH}_{4}$ oxidation. There do exist a few measurements of aerobic $\mathrm{CH}_{4}$ oxidation in marine environments, as well as measurements taken from open systems under oligotrophic regimes (Tilbrook and Karl, 1994, Holmes et al., 2000) which report lower levels of oxidation than in the oxic-anoxic interface (Sansone and Martens, 1978; Reeburgh et al., 1991).

\section{3 $\mathrm{CH}_{4}$ and $\mathrm{N}_{2} \mathrm{O}$ emission in the Southern Ocean}

Highly dynamic gas exchanges were registered in the KPR, with source and sink scenarios for $\mathrm{N}_{2} \mathrm{O}$ and only a source scenario for $\mathrm{CH}_{4}$. Since the mean wind speed did not exceed $14 \mathrm{~m} \mathrm{~s}^{-1}$, LM86 and W92 parameterizations represent the more conservative overestimation estimates of gas exchange in the area (Frost and Upstill-Goddard, 2002). The gas inventories in the ML reflect the effect of gas transport mainly via turbulent mixing and advection, which can be accelerated by the action of wind as well as by the microbial activity in surface waters. The ML depth did not correlate with wind speed (rs: $0.31, p<0.05$ ) and this aids in estimation of the gas content in the ML and whether it is a result of in situ production or consumption. $\mathrm{CH}_{4}$ fluxes were higher at stations located at the PF and A3, where phytoplanktonic blooms were observed (see Table 2), but the tendency was the reverse for $\mathrm{N}_{2} \mathrm{O}$, with an influx into the aforementioned stations. $\mathrm{CH}_{4}$ emission rates during this study were higher than previously measured (Table 2), with a range of 0.1 to $3.0 \mu \mathrm{mol} \mathrm{m} \mathrm{m}^{-2} \mathrm{~d}^{-1}$ for the Pacific Ocean (Bates et al., 1996; Holmes et al., 2000; Sansone et al., 2001) and 0.5 to $9.7 \mu \mathrm{mol} \mathrm{m}{ }^{-2} \mathrm{~d}^{-1}$ for the Atlantic Ocean (Oudot et al., 2002; Forster et al., 2009). In the South Pacific ocean $\left(10^{\circ}-64^{\circ} \mathrm{S}, 140^{\circ} \mathrm{E}\right)$, crossing the $\mathrm{PF}$, Yoshida et al. (2011) reported $\mathrm{CH}_{4}$ fluxes ranging from 2.4 to $4.9 \mu \mathrm{mol} \mathrm{m} \mathrm{m}^{-2} \mathrm{~d}^{-1}$.

In the case of $\mathrm{N}_{2} \mathrm{O}$, the estimates in this study were in the expected range for the oligotrophic open ocean (Nevison et al., 1995). $\mathrm{N}_{2} \mathrm{O}$ undersaturation and the concomitant influx were estimated, although this situation has not yet been well described for the Southern Ocean. $\mathrm{N}_{2} \mathrm{O}$ sinks can occasionally be observed (Butler et al., 1989; Law and Ling, 2001), which can be explained by probable $\mathrm{N}_{2} \mathrm{O}$ assimilation by $\mathrm{N}$ - fixing microorganisms. This process may be responsible for the estimated $\mathrm{N}_{2} \mathrm{O}$ influx.

\section{Implications}

The dynamics of both gases differ substantially both spatially and vertically (surface to $500 \mathrm{~m}$ depth), indicating that different mechanisms are being activated to produce an active gas during recycling. Our findings also show that, in areas of active fertilization and biogenic particle accumulation, $\mathrm{CH}_{4}$ accumulates while $\mathrm{N}_{2} \mathrm{O}$ becomes depleted. This study suggests that the Antarctic Polar Zone plays a significant role in surface $\mathrm{CH}_{4}$ production and subsequent air-sea gas exchange. These results did not agree with some previous studies of artificial fertilization experiments in the Southern Ocean, although only a few studies of this nature exist. This indicates that the turnover and evolution of microbial communities in mesoscale structures are fundamental for the development of substrates and conditions for $\mathrm{CH}_{4}$ regeneration. Surface $\mathrm{N}_{2} \mathrm{O}$ production via nitrification does not seem to respond to spatial patterns of natural iron fertilization, but $\mathrm{N}_{2} \mathrm{O}$ consumption appears to be intensified in areas with higher $\mathrm{dFe}$ supply. However, in subsurface water, $\mathrm{N}_{2} \mathrm{O}$ accumulation seems to take place via nitrification.

Acknowledgements. We would like to thank the captain and crew of the RV Marion Dufresne. We recognize the support of both project leaders (Stephane Blain and Bernard Queguiner). This work was supported through the French Research programme of INSU-CNRS LEFE-CYBER (Les enveloppes fluides et l'environnement - Cycles biogéochimiques, environnement et ressources), the French ANR (Agence Nationale de la Recherche, SIMI-6 programme, ANR-10-BLAN-0614), the French CNES (Centre National d'Etudes Spatiales) and the French Polar Institute IPEV (Institut Polaire Paul-Emile Victor). We are also grateful to Louise Oriol and Stephane Blain for nutrient data and Marine Lasbleiz for the HPLC analysis of chlorophyll measurements. The altimeter and colour/temperature products for the Kerguelen area were produced by Ssalto/Duacs and CLS with support from CNES. We also recognize all our colleagues who contributed to KEOPS 2. C. Fernández and L. Farias were supported by the Proyecto Ecos-Conicyt C09B02 and the International Associated Laboratory MORFUN. C. Fernández received partial support through Fondap no. 15110027. L. Farias performed the analysis of samples obtained in the KEOPS 2 cruise with FONDECYT no. 1120719. This is a contribution to the FONDAP-CONICYT programme (no. 15110009)

Edited by: S. Blain 


\section{References}

Alldredge, A. L. and Cohen, Y.: Can microscale chemical patches persist in the sea?, Microelectrode study of marine snow, fecal pellets, Science, 235, 689-691, doi:10.1126/science.235.4789.689, 1987.

Arrieta, J. M., Weinbauer, M. G., Lute, C., and Hernd, G. J.: Response of bacterioplankton to iron fertilization in the Southern Ocean, Limnol. Oceanogr., 49, 799-808, 2004.

Bates T. B., Kelly, K. C., Johnson, J. E., and Gammon, R. H.: A re-evaluation of the open ocean source of methane to the atmosphere, J. Geophys. Res., 101, 6953-6961, 1996.

Berman-Frank, I., Quigg, A., Finkel Z. V., Irwin A. J., and Haramaty, L.: Nitrogen-fixation strategies and Fe requirements in cyanobacteria, Limnol. Oceanogr., 52, 2260-2269, 2007.

Blain, S., Quéguiner, B., Armand, L., Belviso, S., Bombled, B., Bopp, L.,Bowie, A., Brunet, C., Brussaard, K., Carlotti, F., Christaki, U., Corbiére, A., Durand, I., Ebersbach, F., Fuda, J. L., Garcia, N., Gerringa, L. J. A., Griffiths, F. B., Guigue, C., Guillerm, C., Jacquet, S., Jeandel, C., Laan, P., Lefèvre, D., Lomonaco, C., Malits, A., Mosseri, J., Obernosterer, I., Park, Y. H., Picheral, M., Pondaven, P., Remenyi, T., Sandroni, V., Sarthou, G., Savoye, N., Scouarnec, L., Souhault, M., Thuillers, D., Timmermans, K. R., Trull, T., Uitz, J., Van-Beek, P., Veldhuis, M. J. W., Vincent, D., Viollier, E., Vong, L., and Wagener, T.: Effect of natural iron fertilization on carbon sequestration in the Southern Ocean, Nature, 446, 1070-1075, 2007.

Blain, S., Sarthou, G., and Laan, P.: Distribution of dissolved iron during the natural iron fertilization experiment KEOPS (Kerguelen Plateau, Southern Ocean), Deep-Sea Res. Pt. II, 55, 594-605, doi:10.1016/j.dsr2.2007.12.028, 2008.

Blain, S., Capparos, J., Guéneuguès, A., Obernosterer, I., and Oriol, L.: Distributions and stoichiometry of dissolved nitrogen and phosphorus in the iron-fertilized region near Kerguelen (Southern Ocean), Biogeosciences, 12, 623-635, doi:10.5194/bg-12623-2015, 2015.

Blais, M., Tremblay J.-É., Jungblut, A. D., Gagnon, J., Martin, J., Thaler, M., and Lovejoy, C.: Nitrogen fixation and identification of potential diazotrophs in the Canadian Arctic, Global Biogeochem. Cy., 26, GB3022, doi:10.1029/2011GB004096, 2012.

Butler, J. H., Elkins, J. W., Thompson, T. M., and Egan, K. B.: Tropospheric and Dissolved $\mathrm{N}_{2} \mathrm{O}$ of the West Pacific and East Indian Oceans During the El Niño Southern Oscillation Event of 1987, J. Geophys. Res., 94, 14865-14877, 1989.

Boyd, P. W. and Ellwood M. J. The biogeochemical cycle of iron in the ocean, Nature Geoscience, 3, 675-82, 2010.

Cavagna, A. J., Fripiat, F., Elskens, M., Dehairs, F., Mangion, P., Chirurgien, L., Closset, I., Lasbleiz, M., Flores-Leiva, L., Cardinal, D., Leblanc, K., Fernandez, C., Lefèvre, D., Oriol, L., Blain, S., and Quéguiner, B.: Biological productivity regime and associated $\mathrm{N}$ cycling in the vicinity of Kerguelen Island area, Southern Ocean, Biogeosciences Discuss., 11, 18073-18104, doi:10.5194/bgd-11-18073-2014, 2014.

Chen, L., Zhang, J., Zhan, L., Li, Y., and Sun, H.: Differences in nitrous oxide distribution patterns between the Bering Sea basin and Indian Sector of the Southern Ocean, Acta Oceanol., 33, 919, doi:10.1007/s13131-014-0484-8, 2014.

Chever, F., Sarthou, G., Bucciarelli, E., Blain, S., and Bowie, A. R.: An iron budget during the natural iron fertilisation experiment
KEOPS (Kerguelen Islands, Southern Ocean), Biogeosciences, 7, 455-468, doi:10.5194/bg-7-455-2010, 2010.

Christaki, U., Lefèvre, D., Georges, C., Colombet, J., Catala, P., Courties, C., Sime-Ngando, T., Blain, S., and Obernosterer, I.: Microbial food web dynamics during spring phytoplankton blooms in the naturally iron-fertilized Kerguelen area (Southern Ocean), Biogeosciences, 11, 6739-6753, doi:10.5194/bg-116739-2014, 2014.

Cicerone, R. J. and Oremland, R. S.: Biogeochemical aspects of atmospheric methane, Global Biogeochem. Cy., 2, 299-327, 1988.

Codispoti, L. A. and Christensen, J. P.: Nitrification, denitrification and nitrous oxide cycling in the eastern Tropical South Pacific Ocean, Mar. Chem., 16, 277-300, 1985.

Codispoti, L. A., Brandes, J. A., Christensen, J. P., Devol, A. H., Naqvi, S. W. A., Paerl, H., and Yoshinari, T.: The oceanic fixed nitrogen and nitrous oxide budgets: Moving targets as we enter the anthropocene?, Sci. Mar., 65, 85-105, 2001.

Damm, E., Helmke, E., Thoms, S., Schauer, U., Nöthig, E., Bakker, K., and Kiene, R. P.: Methane production in aerobic oligotrophic surface water in the central Arctic Ocean, Biogeosciences, 7, 1099-1108, doi:10.5194/bg-7-1099-2010, 2010.

Dehairs, F., Fripiat, F., Cavagna, A.-J., Trull, T. W., Fernandez, C., Davies, D., Roukaerts, A., Fonseca Batista, D., Planchon, F., and Elskens, M.: Nitrogen cycling in the Southern Ocean Kerguelen Plateau area: evidence for significant surface nitrification from nitrate isotopic compositions, Biogeosciences Discuss., 11, 13905-13955, doi:10.5194/bgd-11-13905-2014, 2014.

Díez, B., Bergman, B., Pedrós-Alió, C., Antó, M., and Snoeijs, P.: High cyanobacterial nifH gene diversity in Arctic seawater and sea ice brine, Environmental Microbiology Reports, 4, 360-366, doi:10.1111/j.1758-2229.2012.00343.x, 2012.

d'Ovidio, F., Della Penna, A., Trull, T. W., Nencioli, F., Pujol, I., Rio, M. H., Park, Y.-H., Cotté, C., Zhou, M., and Blain, S.: The biogeochemical structuring role of horizontal stirring: Lagrangian perspectives on iron delivery downstream of the Kerguelen plateau, Biogeosciences Discuss., 12, 779-814, doi:10.5194/bgd-12-779-2015, 2015.

Emery, W. J. and Thomson, R. E.: Data analysis methods in physical oceanography, Pergamon Press, 634 pp., 1997.

Farías, L., Fernández, C., Faúndez, J., Cornejo, M., and Alcaman, M. E.: Chemolithoautotrophic production mediating the cycling of the greenhouse gases $\mathrm{N}_{2} \mathrm{O}$ and $\mathrm{CH}_{4}$ in an upwelling ecosystem, Biogeosciences, 6, 3053-3069, doi:10.5194/bg-63053-2009, 2009.

Farías, L., Faundez, J., Fernadez, C., Cornejo, M., Sanhueza, S., and Carrasco, C.: Biological $\mathrm{N}_{2} \mathrm{O}$ fixation in the eastern South Pacific ocean, PLoS One 8, e63956, doi:10.1371/journal.pone.0063956, 2013.

Florez-Leiva, L., Damm, E., and Farías, L.: Methane production induced by methylsulfide in surface water of an upwelling ecosystem, Prog. Oceanogr., 112, 38-48, doi:10.1016/j.pocean.2013.03.005, 2013.

Forster, G., Upstill-Goddard, R. C., Gist, N., Robinson, C., Uher, G., Woodward, E. M.: Nitrous oxide and methane in the Atlantic Ocean between $50^{\circ} \mathrm{N}$ and $52^{\circ} \mathrm{S}$ : Latitudinal distribution and seaair flux, Deep-Sea Res. Pt. II, 56, 964-976, 2009.

Fourquez, M., Obernosterer, I., Davies, D. M., Trull, T. W., and Blain, S.: Microbial iron uptake in the naturally fertilized waters in the vicinity of Kerguelen Islands: phytoplankton- 
bacteria interactions, Biogeosciences Discuss., 11, 1505315086, doi:10.5194/bgd-11-15053-2014, 2014.

Frost, T. and Upstill-Goddard, R. C.: Meteorological controls of gas exchange at a small English lake, Limnol. Oceanogr., 47, 2002, 1165-1174, 2002.

Fuhrman, J. A. and Capone, D. G.: Possible biogeochemical consequences of ocean fertilization, Limnol. Oceanogr., 36, 19511959, 1991.

Grasshoff, J.: Methods of seawater analysis, in: Methods of seawater analysis Verlag chimie Germany, edited by: Grasshoff, K., Ehrhardt, M., Kremling, K., 1983.

González, M. L., Molina, V., Florez-Leiva, L., Oriol, L., Cavagna, A. J., Dehairs, F., Farias, L., and Fernandez, C.: Nitrogen fixation in the Southern Ocean: a case of study of the Fe-fertilized Kerguelen region (KEOPS II cruise), Biogeosciences Discuss., 11, 17151-17185, doi:10.5194/bgd-11-17151-2014, 2014.

Hanson, R. S. and Hanson, T. E.: Methanotrophic bacteria, Microbiol. Mol. Biol. R., 60, 439-471, 1996.

Heeschen, U. K., Keir, R. S., Rehder, G., Klatt, O., and Suess, E.: Methane dynamics in the Weddel Sea determined via stable isotope ratios and CFC-11, Global Biogeochem. Cy., 18, GB2012, doi:10.1029/2003GB002151, 2004.

Holmes, M. E., Sansone, F. J., Rust, T. M., and Popp, B. N.: Methane production, consumption, and air-sea exchange in the open ocean: An evaluation based on carbon isotopic ratios, Global Biogeochem. Cy., 14, 1-10, 2000.

Holmes, R. H., Aminot, A., Kérouel, R., Hooker, B. A., and Peterson, J. A.: simple and precise method for measuring ammonium in marine and freshwater ecosystems, Can. Fish. Aquat. Sci., 56, 1801-1808, 1999.

IPCC, 2013: Climate Change 2013: The Physical Science Basis, Contribution of Working Group I to the Fifth Assessment Report of the Intergovernmental Panel on Climate Change, edited by: Stocker, T. F., Qin, D., Plattner, G.-K., Tignor, M., Allen, S. K., Boschung, J., Nauels, A., Xia, Y., Bex, V., and Midgley, P. M., Cambridge University Press, Cambridge, United Kingdom and New York, NY, USA, 1535 pp., 2013.

Jain, A. K., Briegleb, B. P., Minschwaner, K., and Wuebbles, D. J.: Radiative forcing and global warming potentials of greenhouse gases, J. Geophys. Res., 105, 20773-20790, 2000.

Jin, X. and Gruber, N.: Offsetting the radiative benefit of ocean iron fertilization by enhancing $\mathrm{N}_{2} \mathrm{O}$ emissions, J. Geophys. Res., 30, 2249, doi:10.1029/2003GL018458, 2003.

Karl, D., Beversdorf, L., Björkman, K. M., Church, M. J., Martinez, A., and DeLong, E. F.: Aerobic production of methane in the sea, Nat. Geosci., 1, 473-478, 2008.

Karl, D. M. and Tilbrook, B. D.: Production and transport of methane in oceanic particulate matter, Nature, 368, 732-734, 1994.

Kiene, R. P., Linn, L. J. J., Gonzalez, J. M. A., Moran, M. A., and Bruton, J. A.: Dimethylsulfoniopropionate and methanethiol are important precursors of methionine and protein-sulfur in marine bacterioplankton, Appl. Environ. Microb., 65, 4549-4558, 1999.

Kirchman, D. I., Hoffman, K. A., Weaver, R., and Hutchins, D. A.: Regulation of growth and energetics of a marine bacterium by nitrogen source and iron availability, Mar. Ecol. Prog. Ser., 250, 291-296, 2003.
Lamontagne, R., Swinnerton, J. W., Linnenbom, V. J., and Smith, W. D.: Methane concentrations in various marine environments, J. Geophys. Res., 78, 5317-5324, 1973.

Lasbleiz, M., Leblanc, K., Blain, S., Ras, J., Cornet-Barthaux, V., Hélias Nunige, S., and Quéguiner, B.: Pigments, elemental composition $(\mathrm{C}, \mathrm{N}, \mathrm{P}$, and $\mathrm{Si})$, and stoichiometry of particulate matter in the naturally iron fertilized region of Kerguelen in the Southern Ocean, Biogeosciences, 11, 5931-5955, doi:10.5194/bg-115931-2014, 2014.

Laurenceau-Cornec, E. C., Trull, T. W., Davies, D. M., Bray, S. G., Doran, J., Planchon, F., Carlotti, F., Jouandet, M.-P., Cavagna, A.-J., Waite, A. M., and Blain, S.: The relative importance of phytoplankton aggregates and zooplankton fecal pellets to carbon export: insights from free-drifting sediment trap deployments in naturally iron-fertilised waters near the Kerguelen Plateau, Biogeosciences, 12, 1007-1027, doi:10.5194/bg-121007-2015, 2015.

Law, C. and Ling, R.: Nitrous oxide flux and response to increased iron availability in the Antarctic Circumpolar Current, Deep-Sea Res. Pt. II, 48, 2509-2527, 2001.

Liss, P. S. and Merlivat, L.: Air-sea gas exchange rates: Introduction and synthesis, in: The Role of Air-Sea Exchange in Geochemical Cycling, edited by: Buat-Menard, P. and Reidel, D., Dordrecht, 25, 113-127, 1986.

Mills, M. M., Ridame, C., Davey, M., La Roche, J., and Geider, R.: Iron and phosphorus co-limit nitrogen fixation in the eastern tropical North Atlantic, Nature, 429, 292-294, 2004.

Mongin, M., Molina, E., and Trull, T.: Seasonality and scale of the Kerguelen plateau phytoplankton bloom: A remote sensing and modeling analysis of the influence of natural iron fertilization in the Southern Ocean, Deep-Sea Res. Pt. II, 55, 880-892, 2008.

Moore, C. M, Mills, M. M., Achterberg, E. P., Geider, R. J., LaRoche, J., Lucas, M. I., McDonagh, E. L., Pan, X., Poulton, A. J., Rijkenberg, M. J. A., Suggett, D. J., Ussher, S. J., and Woodward, E. M. S.: Large-scale distribution of Atlantic nitrogen fixation controlled by iron availability, Nat. Geosci., 2, 867-871, 2009.

Morel, F. M. M. and Price, N. M.: The biogeochemical cycles of trace metals in the Oceans, Science, 300, 944-947, doi:10.1126/science.1083545, 2003.

Morel, F. M. M., Milligan, A. J., and Saito, M. A.: Marine Bioinorganic Chemistry: The Role of Trace of Metals in the Oceanic Cycles of Major Nutrients in: Treatise on Geochemistry, Vol. 6, edited by: Turekian, K. K. and Holland, H. D., Elsevier Science Ltd, Cambridge, UK, 113-143, 2003.

Nevison, C., Weiss, R., and Erickson III, D. J.: Global oceanic emissions of nitrous oxide, J. Geophys. Res., 100, 15809-15820, 1995.

Nevison, C., Butler, J. H., and Elkins, J. W.: Global distribution of $\mathrm{N}_{2} \mathrm{O}$ and the $\mathrm{DN}_{2} \mathrm{O}-\mathrm{AOU}$ yield in the subsurface ocean, Global Biogeochem. Cy., 7, 1119, doi:10.1029/2003GB002068, 2003.

Oschlies, A., Koeve, W., Rickels, W., and Rehdanz, K.: Side effects and accounting aspects of hypothetical large-scale Southern Ocean iron fertilization, Biogeosciences, 7, 4017-4035, doi:10.5194/bg-7-4017-2010, 2010.

Oudot, C., Jean-Baptiste, P. E. Fourreb, E., Mormichea, C., Guevela, M., Ternonc, J.-F., and Le Corred, P.: Transatlantic equatorial distribution of nitrous oxide and methane, Deep-Sea Research Pt. I, 49, 1175-1193, 2002. 
Park, Y.-H. and Vivier, F.: Circulation and hydrography over the Kerguelen Plateau, Marine ecosystems and fisheries, 5, 43-55, 2012.

Park, Y.-H., Durand, I., Kestenare, E., Rougier, G., Zhou, M., d'Ovidio, F., Cotté, C., and Lee, J.-H.: Polar Front around the Kerguelen Islands: An up-to-date determination and associated circulation of surface/subsurface waters, J. Geophys. Res.Oceans, 119, 6575-6592, doi:10.1002/2014JC010061, 2014.

Quéroué, F., Sarthou, G., Planquette, H. F., Bucciarelli, E., Chever, F., van der Merwe, P., Lannuzel, D., Townsend, A. T., Cheize, M., Blain, S., d'Ovidio, F., and Bowie, A. R.: High variability of dissolved iron concentrations in the vicinity of Kerguelen Island (Southern Ocean), Biogeosciences Discuss., 12, 231-270, doi:10.5194/bgd-12-231-2015, 2015.

Reeburgh, W. S.: Oceanic methane biogeochemistry, Chem. Rev., 107, 486-513, 2007.

Reeburgh, W. S., Ward, B. B., Whalen, S. C., and Sandbeck, K. A., Kilpatrick, L. J., and Kerkhof, K.: Black Sea methane geochemistry, Deep-Sea Res. Pt. II, 38, S1189-S1210, 1991.

Rees, A. P., Owens, N. J. P., and Upstill-Goddard, R. C.: Nitrous oxide in the Bellingshausen Sea and Drake Passage, J. Geophys. Res., 102, 3383-3391, 1999.

Rehder, G., Keir, R. S., Suess, E., and Rhein, M.: Methane in the northern Atlantic controlled by microbial oxidation and atmospheric history, Geophys. Res. Lett., 26, 587-590, 1999.

Rhee, T. S., Kettle, A. J., and Andreae, M. O.: Methane and nitrous oxide emissions from the ocean: A reassessment using basin-wide observations in the Atlantic, J. Geophys. Res., 114, D12304, doi:10.1029/2008JD011662, 2009.

Sanial, V., van Beek, P., Lansard, B., Souhaut, M., Kestenare, E., d'Ovidio, F., Zhou, M., and Blain, S.: Use of Ra isotopes to deduce rapid transfer of sediment-derived inputs off Kerguelen, Biogeosciences Discuss., 11, 14023-14061, doi:10.5194/bgd11-14023-2014, 2014.

Sansone, F. J. and Martens, C. S.: Methane oxidation in Cape Lookout Bight, North Carolina, Limnol. Oceanogr., 23, 349-355, 1978.

Sansone, F. J., Popp, B. N., Gasc, A., Graham, W., and Rust, T. M.: Highly elevated methane in the eastern tropical North Pacific and associated isotopically enriched fluxes to the atmosphere, Geophys. Res. Lett., 28 4567-4570, 2001.

Sarmiento, J. L. and Gruber, N.: Ocean Biogeochemical Dynamics, Princeton University Press, 2006.

Scranton, M. I. and Brewer, P.: Occurrence of methane in the nearsurface waters of the western subtropical North Atlantic, DeepSea Res., 24, 127-138, 1977.

Simó, R., Archer, S. D., Pedró-Alió, C., Gilpin, L., and StelfoxWiddicombe, C. E.: Coupled dynamics of dimethyl- sulfoniopropionate and dimethylsulfide cycling and the microbial food web in surface waters of the North Atlantic, Limnol. Oceanogr., 47, 53-61, 2002.

Sun, J., Steindler, L., Thrash, C. J., Halsey, K. H., Smith, D. P., Carter, A. E., Zachary, C. L., and Giovannoni, S. J.: One Carbon Metabolism in SAR11 Pelagic Marine Bacteria, PloS one, e23973, doi:10.1371/journal.pone.0023973, 2011.
Tilbrook, E. D. and Karl, D. M.: Dissolved methane distributions, sources, and sinks in the western Bransfield Strait, Antarctica, J. Geophys. Res., 99, 16383-16393, 1994.

Tréguer, P. and Le Corre, P.: Manuel d'analyse des sels nutritifs dans I'eau de mer Utilisation de 1'AutoAnalyzt-r 2 Technicon, 2nd edn., Univ Bretagne occidentale, Brest, 1975.

van der Merwe, P., Bowie, A. R., Quéroué, F., Armand, L., Blain, S., Chever, F., Davies, D., Dehairs, F., Planchon, F., Sarthou, G., Townsend, A. T., and Trull, T. W.: Sourcing the iron in the naturally fertilised bloom around the Kerguelen Plateau: particulate trace metal dynamics, Biogeosciences, 12, 739-755, doi:10.5194/bg-12-739-2015, 2015.

Vila-Costa, M., Simó, R., Harada, H., Gasol, J. M., Slezak, D., and Kiene, R. P.: Dimethylsulfoniopropinate uptake by marine phytoplankton, Science, 314, 652-654, 2006.

Vissher, P. T., Kiene, R. P., and Taylor, B. F.: Demethylation and cleavage of demethylsulfoniopropionate in marine intertidal sediments, FEMS Microbiol. Ecol., 14, 179-190, 1994.

Walter, S., Peeken, I., Lochte, K., and Bange, H. W.: Nitrous oxide measurements during EIFEX, the European Iron Fertilisation Experiment in the subpolar South Atlantic Ocean, Geophys. Res. Lett., 32, L23613, doi:10.1029/2005GL024619, 2005.

Wanninkhof, R.: Relationship between wind speed and gas exchange over the ocean, J. Geophys. Res., 97, 7373-7382, 1992.

Wiesenburg, D. A. and Guinasso, N. L.: Equilibrium solubilities of methane, carbon monoxide and hydrogen in water and seawater, J. Chem. Eng. Data, 24, 354-360, 1979.

Weiss, R. F. and Prince, B. A.: Nitrous oxide solubility in water and seawater, Mar. Chem., 8, 347-359, 1980.

Weller D. I., Law, C. S. A. Marriner, A., Nodder, S. D., Chang, F. H., Stephens, J. A., Wilhelm, S. W., Boyd, P. W., and Sutton, P. J. H.: Temporal variation of dissolved methane in a subtropical mesoscale eddy during a phytoplankton bloom in the southwest Pacific Ocean, Prog. Oceanogr., 116, 193-206, 2013.

Wingenter, O. W., Haase, K. B., Strutton, P., Friedrich, G., Meinardi, S., Blake, D. R., and Rowland, F. S.: Changing concentrations of $\mathrm{CO}, \mathrm{CH}_{4}, \mathrm{C}_{5} \mathrm{H} 8, \mathrm{CH}_{3} \mathrm{Bt}, \mathrm{CH}_{3} \mathrm{I}$ and dimethyl sulfide during the Southern Ocean Iron Enrichment Experiments, P. Natl. Acad. Sci., 101, 8537-8541, 2004.

Wuebble, D. J. and Hayhoe, K.: Atmospheric methane and global change, Earth-Sci. Rev., 57, 177-210, 2002.

Yoch, D.: Dimethylsulfoniopropionate: Its Sources, Role in the Marine Food Web, and Biological Degradation to Dimethylsulfide, Appl. Environ. Microb., 68, 5804-5815, doi:10.1128/AEM.68.12.5804-5815.2002, 2002.

Yoshida, O., Inoue, H. Y., Watanabe, S., Suzuki, K., and Noriki, S.: Dissolved methane distribution in the South Pacific and the Southern Ocean in austral summer, J. Geophys. Res., 116, C07008, doi:10.1029/2009JC006089, 2011.

Zhou, M., Zhu, Y., d'Ovidio, F., Park, Y.-H., Durand, I., Kestenare, E., Sanial, V., Van-Beek, P., Queguiner, B., Carlotti, F., and Blain, S.: Surface currents and upwelling in Kerguelen Plateau regions, Biogeosciences Discuss., 11, 6845-6876, doi:10.5194/bgd-116845-2014, 2014. 